\title{
CrystEngComm
}

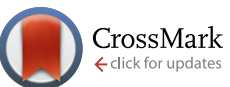

Cite this: CrystEngComm, 2015, 17, 2737

Received 26th January 2015,

Accepted 24th February 2015

DOI: $10.1039 / c 5 c e 00180 c$

www.rsc.org/crystengcomm

\section{Crystalline inclusion properties of new pyridine and thiophene modified wheel-and-axle diol hosts $\uparrow$}

\author{
Felix Katzsch and Edwin Weber*
}

\begin{abstract}
Structural extension of the 'wheel-and-axle' host concept has given rise to the design of a new type of host derivative (1-3) featuring two di(pyrid-2-yl)hydroxymethyl or di(thien-2-yl)hydroxymethyl moieties attached to a central phenylene unit, i.e. having the phenyl groups of a well-known model compound ( $\mathrm{Ph}$ ) substituted by heteroaromatics. Syntheses of the new derivative compounds are described, and the capability to form crystalline inclusions obtained from solvent solution compared to the prototype molecule is studied, including X-ray diffraction analysis of relevant crystal structures. Sorption measurements of the compounds as solid receptor films coated on a quartz crystal microbalance considering a variety of solvent vapors have been performed, showing potential application as mass sensitive sensor materials.
\end{abstract}

\section{Introduction}

Due to their potential uses in a variety of fundamental and practical issues such as compound separation and storage, ${ }^{1-4}$ crystalline inclusion compounds ${ }^{5-8}$ are a very challenging field in supramolecular chemistry ${ }^{9}$ including crystal engineering. ${ }^{10-12}$ This encouraged the development of appropriate host molecules that are effective in the corresponding behavior patterns. ${ }^{13,14}$ With reference to the different lines of structural design, hosts based on coordinato-clathrate ${ }^{15,16}$ and wheeland-axle strategies ${ }^{17,18}$ are perhaps the most useful. A prototype host molecule derived from this line of thought, featuring two bulky diphenylhydroxymethyl moieties attached at positions 1 and 4 to a phenylene unit, is given with the formula Ph in Fig. 1. 19,20 Not only this particular compound but also its derivatives, showing a variety of substituents, are distinguished by a wide range of inclusion formation properties. ${ }^{21}$ Nevertheless, notwithstanding some few related structures of heteroaromatic group containing diols possessing, however, the heterocycle in the axle position or that differ in the axle element, ${ }^{22}$ concrete analogues of $\mathbf{P h}$ showing the phenyl residues substituted by heterocycles such as pyridyl or thienyl units have not been described so far. ${ }^{23-25}$ Actually,

Institute of Organic Chemistry, Technical University Bergakademie Freiberg,

Leipziger Straße 29, D-09596 Freiberg, Sachsen, Germany.

E-mail: edwin.weber@chemie.tu-freiberg.de

$\dagger$ Electronic supplementary information (ESI) available: The crystallographic information files have been deposited in the Cambridge Structural Database. CCDC 1020736 (1), 1020737 (1a), 1020738 (1b), 1020740 (2a), 1020739 (2b), 1020741 (3A), 1020742 (3B), and 1020743 (3C). The DSC diagrams are included as supplementary figures (Sup. 1 and Sup. 2). For ESI and crystallographic data in CIF or other electronic format see DOI: 10.1039/c5ce00180c this is a remarkable fact since, as a consequence of the replacement, a change in the crystal packing and specifically modified inclusion behavior might be expected. As for that, this should especially apply to the pyridino derivative of $\mathbf{P h}$ providing additional acceptor sites for hydrogen bonding by means of the pyridine nitrogens. On the other hand, pyridyl and thienyl are spatially very similar to phenyl (isosterism), ${ }^{26}$ and beyond that, in the latter case, also concerning electronics being, e.g., expressed by the finding that an exchange of phenyl for thienyl in a drug molecule mostly conserves the pharmaceutical effect (bioisosterism). ${ }^{27}$ In order to prove the above presumptions, the corresponding pyridyl and thienyl derivatives of Ph (Fig. 1), i.e. 1 and 2, respectively, were synthesized and comparatively studied with reference to the formation of crystalline inclusion compounds. Considering a structural modification of 1 , compound 3 (Fig. 1) featuring a 1,3- instead of a 1,4-connected phenylene unit has been included in the respective study. Furthermore, we give a detailed report on the relevant crystal structures of the corresponding solvent inclusions that have been isolated (1a, $\mathbf{1 b}$, $2 \mathrm{a}$ and $2 \mathrm{~b}$ ) and of the solvent-free compounds ( 1 and 3 ) with the latter existing in three different polymorphs (3A-3C). Finally, the results of vapor sorption using a quartz crystal microbalance (QCM) ${ }^{28}$ with 1 and 2 are discussed, and conclusions are drawn from all the findings.

\section{Results and discussion}

\section{Preparation of compounds}

Diols 1 and 3 were synthesized from 2-pyridyl lithium (obtained from 2-bromopyridine and $n$-butyl lithium in dry $\mathrm{THF}$ at $-78{ }^{\circ} \mathrm{C}$, under argon) and terephthaloyl or 
<smiles>OC(c1ccccc1)(c1ccccc1)c1ccc(C(O)(c2ccccc2)c2ccccc2)cc1</smiles>

$\mathrm{Ph}$<smiles>OC(c1ccc(C(O)(c2ccccn2)c2ccccn2)cc1)(c1ccccn1)c1ccccn1</smiles>

1<smiles>OC(c1ccc(C(O)(c2cccs2)c2cccs2)cc1)(c1cccs1)c1cccs1</smiles>

2

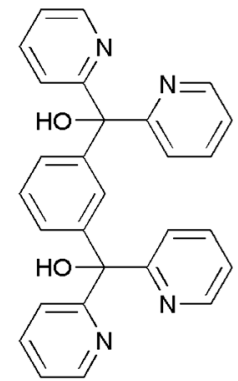

3

$$
\begin{aligned}
& 1=\text { solvent free } \\
& 1 \mathbf{a}=1 \cdot \text { dioxane }(1: 1) \\
& 1 \mathbf{b}=1 \cdot \text { toluene }(1: 2)
\end{aligned}
$$

\section{$\mathbf{2 a}=\mathbf{2} \cdot$ dioxane $(1: 1)$ $\mathbf{2} \mathbf{b}=\mathbf{2} \cdot$ pyrrolidine $(1: 2)$}

$3 A=3($ polymorph $A)$
$3 B=3($ polymorph $B)$
$3 C=3($ polymorph $C)$

Fig. 1 Compounds studied in this paper (for the purpose of comparison, $\mathrm{Ph}$ is designated as the known wheel-and-axle host analogue).

isophthaloyl chloride, respectively, yielding the compounds as beige solids. Imitating a described procedure, ${ }^{29}$ diol 2 was prepared by reaction of 2-thienyl lithium (from thiophene and $n$-butyl lithium in dry THF at $-30{ }^{\circ} \mathrm{C}$, under argon) and dimethyl terephthalate, resulting in a white solid. Inclusion compounds $1 \mathrm{a}, \mathbf{1 b}, \mathbf{2 a}$, and $2 \mathrm{~b}$ were obtained by recrystallization of 1 and 2, respectively, from the respective solvents.

\section{Capability of inclusion formation}

To investigate the potency of solids 1-3 as hosts for crystalline inclusion formation, they were crystallized from a variety of solvents ranging from dipolar protic via dipolar aprotic to largely apolar species and involving solvents of acyclic and cyclic as well as of aliphatic and aromatic or heteroaromatic nature. Both specification of the solvents and findings obtained from this study are summarized in Table 1;

Table 1 Inclusion compounds formed from diol hosts 1 and 2 and from the literature known benzene analogue $\mathrm{Ph}$

\begin{tabular}{llll}
\hline & Ph & $\mathbf{1}$ & $\mathbf{2}$ \\
\hline MeOH & - & - & - \\
EtOH & - & - & - \\
$n$-PrOH & - & - & $1: 2$ \\
$n$-BuOH & - & - & $1: 2$ \\
i-PrOH & $3: 2$ & - & - \\
$t$-BuOH & $2: 1$ & - & - \\
Acetone & $2: 1$ & - & $2: 1$ \\
Acetonitrile & $2: 1$ & - & - \\
Nitromethane & $2: 1$ & - & - \\
DMF & $1: 2$ & - & - \\
DMSO & $1: 2$ & - & - \\
Et ${ }_{2}$ NH & - & - & - \\
Toluene & - & $1: 2(\mathbf{1 b})$ & $c$ \\
Pyridine & $1: 2$ & - & $1: 1(\mathbf{2 a})$ \\
THF & $2: 1$ & - & $1: 2(\mathbf{2 b})$ \\
1,4-Dioxane & $1: 2$ & $1: 1(\mathbf{1 a})$ & $c$ \\
Pyrrolidine & - & - & $c$ \\
Morpholine & $1: 1$ & - & \\
Piperidine & $1: 2$ & - &
\end{tabular}

$c$-difficult to crystallize. previous results for $\mathbf{P h}$ are also included for comparison. ${ }^{19-21}$ The most remarkable observation is that under the given conditions, the 1,3-connected pyridino diol 3 totally failed in the inclusion formation and is thus excluded in the table. However, crystallization of 3 from different solvents or work-up of reaction product yielded three polymorphous crystals (3A-3C) of which one (3A) has been isolated only as an irreproducible result, which is discussed in more detail below. On the other hand, the formation of solvent inclusions of the 1,4-connected pyridino and thiopheno diols 1 and 2, respectively, was successful although, compared to the efficiency of $\mathbf{P h}$, highly limited in number. Particularly, this is the case of 1 giving only stoichiometric $1: 1$ and $1: 2$ inclusions with 1,4-dioxane (1a) and toluene (1b). Hence, it seems to be clear that $\mathbf{1}$ is only effective in inclusion formation with apolar solvents, and also one should think that the pyridine nitrogens are not involved in a specific host-guest interaction but are possibly used up for intramolecular hydrogen bonding to the hydroxyl groups. Nevertheless, in comparison with the pyridine derivative 1, the thiophene analogue is more effective in solvent inclusion, giving rise to successful isolation of at least six inclusion species, involving $n-\mathrm{PrOH}, n-\mathrm{BuOH}$, acetone, DMSO, 1,4-dioxane (2a) and pyrrolidine (2b) as guest solvents. This means that 2 is rather broad in solvent inclusion but actually does not come near to Ph (12 substantiated inclusions). For all that, $\mathbf{2}$ is superior to $\mathbf{P h}$ in the inclusion of the linear medium-sized alcohols $n$-PrOH and $n$ - $\mathrm{BuOH}$. In this latter respect, $\mathbf{2}$ and $\mathbf{P h}$ behave exactly opposite, whereas considering the failure to include the small alcohols $\mathrm{MeOH}$ and $\mathrm{EtOH}$, they are just the same.

In order to gain more information about the possible reasons for the different behavior patterns of inclusion regarding the studied host compounds and including also the solvent-free species, X-ray structural analysis was undertaken.

\section{X-ray structural study}

Certainly, single crystals qualified for X-ray structural analysis have been obtained for the 1,4-dioxane (1a) and toluene (1b) 
inclusions of 1 , but as far as 2 is concerned, suitable crystals could only be isolated from the inclusions with 1,4-dioxane (2a) and pyrrolidine (2b). Nevertheless, in some ways, a reasonable structural comparison is possible, in particular referring to the 1,4-dioxane inclusions 1a and 2a. Moreover, 1 and 3 (this latter compound exists in three different polymorphs) yielded suitable crystals for an X-ray study allowing further insight into structural circumstances. Crystallographic details and refinement parameters are summarized in Table 2.

\section{Crystal structures involving pyridino diol 1}

The solvent-free structure of pyridino diol 1 crystallizes as colorless prisms in the monoclinic space group $P 2_{1} / c$ from DMSO, DMF, acetone, pyridine and $\mathrm{CHCl}_{3}$ containing half a molecule in the asymmetric part of the unit cell. By way of contrast, the solvent inclusions of 1 with 1,4-dioxane 1a (1:1) and toluene $1 \mathrm{~b}(1: 2)$ crystallize in the triclinic space group $P \overline{1}$. The asymmetric part of the unit cell of $1 \mathrm{a}$ contains half a host and half a guest molecule. Due to the heavy disorder of toluene in $\mathbf{1 b}$, the appropriate electron density was removed by the SQUEEZE method of the PLATON program, ${ }^{30}$ and consequently, the structure was refined without a solvent. Therefore, the asymmetric part of the unit cell in Fig. 2c shows only half a host entity. The molecular structures of all compounds connected with 1 are illustrated in Fig. 2 . The respective conformations of the diol molecules in $\mathbf{1}, \mathbf{1 a}$ and $\mathbf{1 b}$ can be compared by the torsion angles of the pyridine and benzene rings with regard to the hydroxyl groups whereby only slight differences are recognizable (Table 3 ). This can be explained by the stabilizing intramolecular $\mathrm{O}-\mathrm{H} \cdots \mathrm{N}$ and $\mathrm{C}-$ $\mathrm{H} \cdots \mathrm{N}$ interactions specified together with the intermolecular interactions in Table 4.

In the solvent-free structure of $\mathbf{1}$, the diol molecules are arranged in strands in the direction of the crystallographic $a$-axis connected by the $\mathrm{C}-\mathrm{H} \cdots \pi$ interaction ${ }^{31} \mathrm{C} 8-\mathrm{H} 8 \cdots \mathrm{Cg} 3$ $[d(\mathrm{C} 8 \cdots \mathrm{Cg} 3)=3.564(2) \AA]$ as shown in Fig. 3a. Along the $c$-axis, the host strands are linked by weak $\mathrm{C}-\mathrm{H} \cdots \mathrm{O}$ hydrogen bonds $^{32,33} \mathrm{C} 2-\mathrm{H} 2 \cdots \mathrm{O} 1[d(\mathrm{C} 2 \cdots \mathrm{O} 1)=3.221(2) \AA]$ and C9$\mathrm{H} 9 \cdots \mathrm{O} 1[d(\mathrm{C} 9 \cdots \mathrm{O} 1)=3.457(2) \AA]$, while in the $b$-direction, only $\pi \cdots \pi$ contacts between pyridine rings exist. ${ }^{34}$ The packing structure (Fig. 3b) offers no solvent accessible void, and consequently, a packing index $(\mathrm{KPI})^{35}$ of $70.1 \%$ was determined.

Inclusion compounds $\mathbf{1 a}$ and $\mathbf{1 b}$ consist of chain-like connected aggregates of host molecules that are stabilized along the $c$-axis by a hydrogen bond ring motif with the Etter/Bernstein graph $\operatorname{set}^{36,37} R_{2}^{2}(10)$ highlighted for 1a in Fig. 4. Here, strong $\mathrm{O}-\mathrm{H} \cdots \mathrm{N}$ interactions ${ }^{38} \mathrm{O} 1-\mathrm{H} 1 \cdots \mathrm{N} 1$ $[d(\mathrm{O} 1 \cdots \mathrm{N} 1)=2.984(1) \AA(1 \mathrm{a})$ and $d(\mathrm{O} 1 \cdots \mathrm{N} 1)=2.994(1) \AA(1 \mathrm{~b})]$ are involved. These chains are linked in the $a$-direction by the $\mathrm{C}-\mathrm{H} \cdots \mathrm{O}$ hydrogen bond $\mathrm{C} 4-\mathrm{H} 4 \cdots \mathrm{O} 1[d(\mathrm{C} 4 \cdots \mathrm{O} 1)=$ $3.342(2) \AA(1 \mathrm{a})$ and $d(\mathrm{C} 4 \cdots \mathrm{O} 1)=3.347(1) \AA$ (1b)], while in addition $\mathrm{C}-\mathrm{H} \cdots \pi$ contacts $\mathrm{C} 3-\mathrm{H} 3 \cdots \mathrm{Cg} 3 \quad[d(\mathrm{C} 3 \cdots \mathrm{Cg} 3)=$ $3.790(1) \AA(1 \mathrm{a})$ and $d(\mathrm{C} 3 \cdots \mathrm{Cg} 5)=3.775(2) \AA(1 \mathrm{~b})]$ occur between methine groups of the pyridines and the benzene rings. The chains of $\mathbf{1 a}$ are connected by means of $\mathrm{C}-\mathrm{H} \cdots \pi$ interactions $[d(\mathrm{C} 9 \cdots \mathrm{Cg} 1)=3.636(1) \AA]$ along the $b$-axis, whereas the stabilization of $\mathbf{1 b}$ is achieved by a hydrogen bond ring motif with the graph set $\mathrm{R}_{2}^{2}(6)$ containing $\mathrm{C}-\mathrm{H} \cdots \mathrm{N}$ contacts $^{32}[d(\mathrm{C} 10 \cdots \mathrm{N} 2)=3.527(2) \AA]$. Thus, solvent channels are formed along the $a$-axis containing 1,4-dioxane (1a, ca. $4.5 \times 6.8 \AA^{2}$ ) and toluene $\left(1 \mathrm{~b}\right.$, ca. $\left.6.1 \times 8.4 \AA^{2}\right)$, respectively (Fig. 5). The 1,4-dioxane molecules in 1a are fixed in the channels via weak $\mathrm{C}-\mathrm{H} \cdots \mathrm{O}$ contacts $[d(\mathrm{C} 1 \mathrm{G} \cdots \mathrm{O} 1)=3.570(2)$ $\AA$, $d(\mathrm{C} 8 \cdots \mathrm{O} 1 \mathrm{G})=3.305(2) \AA$ and $d(\mathrm{C} 14 \cdots \mathrm{O} 1 \mathrm{G})=3.468(2) \AA]$ in which the guest oxygen $01 \mathrm{G}$ is inversely bifurcated and the hydroxyl oxygen $\mathrm{O} 1$ is inversely trifurcated. As a result of the dioxane connection, a further hydrogen bond ring motif with the graph set $\mathrm{R}_{2}^{2}(8)$ is formed (Fig. 4). In addition, $\mathrm{C}-\mathrm{H} \cdots \mathrm{N}$ interactions $[d(\mathrm{C} 2 \mathrm{G} \cdots \mathrm{N} 2)=3.382(2) \AA]$ exist between the methylene group of the dioxane and the pyridine nitrogen.

The toluene guest solvent in the structure of $\mathbf{1 b}$ is probably connected only by very weak interactions. Therefore, the high thermal motion prevents the refinement of the solvent molecules. Accordingly, the corresponding electron density was removed and the structure was refined without toluene. A solvent accessible void of $285.4 \AA^{3}$, which equates to $37.3 \%$ of the unit cell, gives rise to a $1: 2$ host: guest stoichiometry, and the structure features a packing index (KPI) of $50.2 \%$ without a guest. In order to compare $\mathbf{1 b}$ with the dioxane inclusion compound 1a, the solvent was also removed from 1a yielding a solvent accessible void of $184.5 \AA^{3}$, which equates to $26.8 \%$ of the unit cell (1:1 stoichiometry). Moreover, 1a features packing indices of $55.8 \%$ without dioxane and $67.7 \%$ with dioxane.

\section{Crystal structures involving thiopheno diol compound 2}

Thiopheno diol 2 crystallizes from 1,4-dioxane as a $1: 1$ hostguest inclusion (2a) in the triclinic space group $P \overline{1}$, while crystallization from pyrrolidine results in the formation of a 1:2 solvent inclusion (2b) in the monoclinic space group $P 2_{1} / c$. The asymmetric parts of the unit cells contain half a dioxane molecule (2a) and half a host molecule as well as a pyrrolidine (2b), respectively, as shown in Fig. 6. A similarity in the molecular conformations of $\mathbf{2 a}$ and $\mathbf{2 b}$ is obvious regarding the torsion angles of the thiophene and benzene rings with respect to the hydroxyl groups (Table 3). Nevertheless, the packing arrangements of both structures markedly differ from each other (Fig. 7). Non-covalent interactions of $2 \mathbf{a}$ and $\mathbf{2 b}$ are summarized in Table 5.

The host molecules of $\mathbf{2 a}$ are chain-like connected in the [111]-direction by $\mathrm{S} \cdots \mathrm{O}^{39}[d(\mathrm{~S} 2 \cdots \mathrm{O} 1)=3.319(3) \AA]$ and $\mathrm{S} \cdots \mathrm{S}^{40}$ $[d(\mathrm{~S} 2 \cdots \mathrm{S} 2)=3.533(3) \AA]$ contacts. ${ }^{41,42}$ Along the $a$-axis, $\mathrm{C}-\mathrm{H} \cdots \pi$ interactions $[d(\mathrm{C} 7 \cdots \mathrm{Cg} 4)=3.665(2) \AA]$ stabilize the structure, while in the $b$-direction the host molecules form strands linked by $\mathrm{C}-\mathrm{H} \cdots \pi$ contacts $[d(\mathrm{C} 4 \cdots \mathrm{Cg} 2)=3.553(2) \AA]$. This gives rise to the formation of solvent channels ( $c a .2 .8 \times$ $4.2 \AA^{2}$ ) along the crystallographic $a$-axis (Fig. 8a) in which the dioxane is fixed by strong $\mathrm{O}-\mathrm{H} \cdots \mathrm{O}[d(\mathrm{O} 1 \cdots \mathrm{O} 1 \mathrm{G})=2.810(2) \AA]$ and weak $\mathrm{C}-\mathrm{H} \cdots \mathrm{O}[d(\mathrm{C} 12 \cdots \mathrm{O} 1 \mathrm{G})=3.483(2) \AA]$ hydrogen bonds 


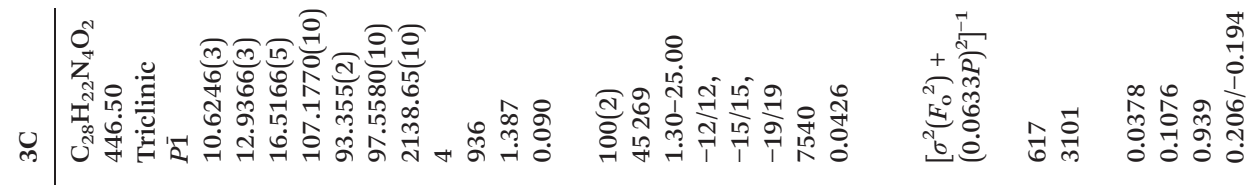

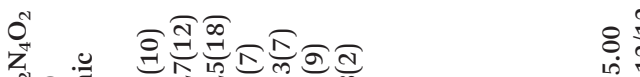

$8 \frac{1}{8} \frac{1}{4}$

लै

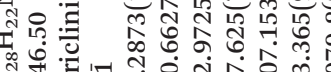

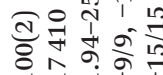

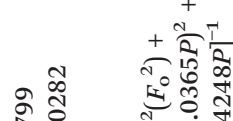

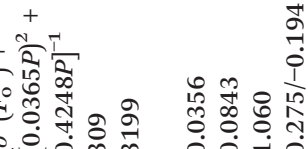

(

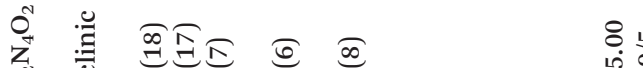

๙

z

臹

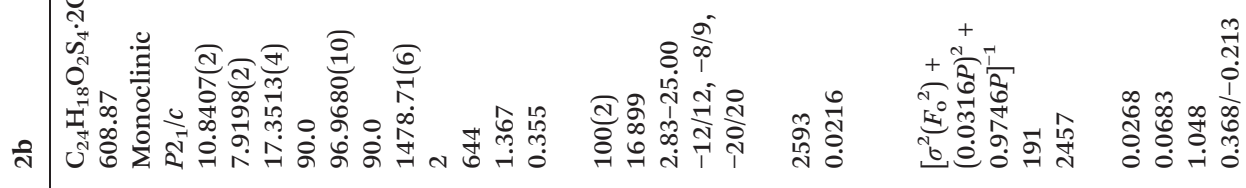

$\underbrace{\infty}_{\substack{\infty \\ j}}$

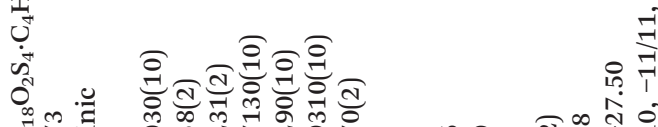

$+\frac{20}{\sqrt[4]{4}}$

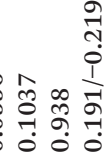

I

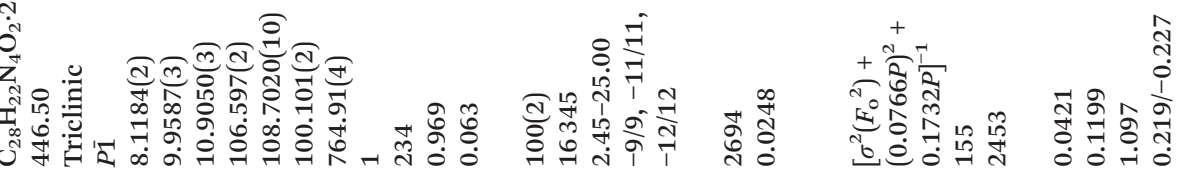

垔

侘

苟。苟

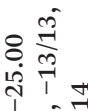

弯

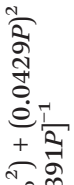

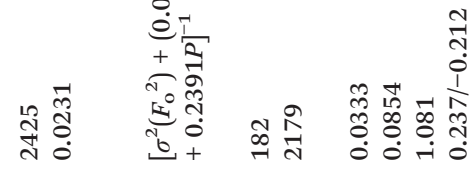




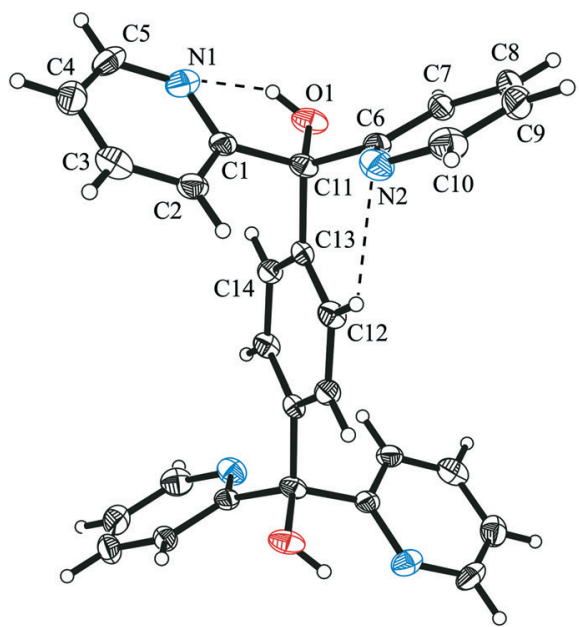

(a)

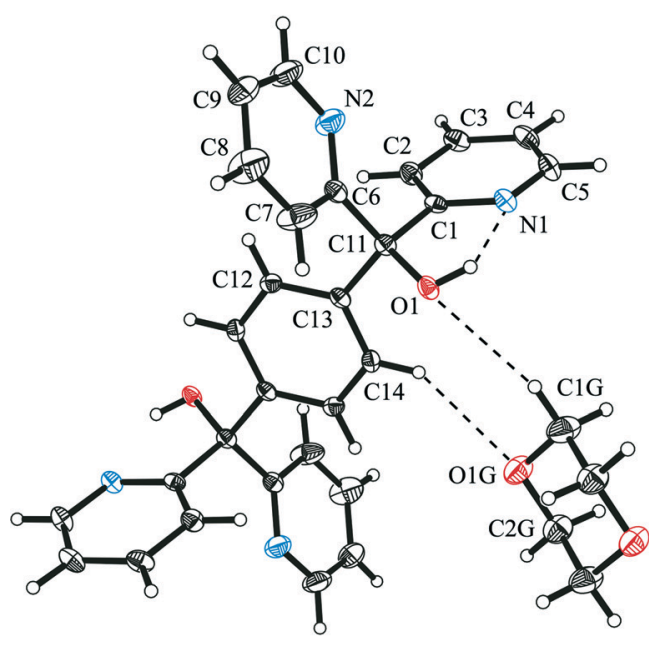

(b)

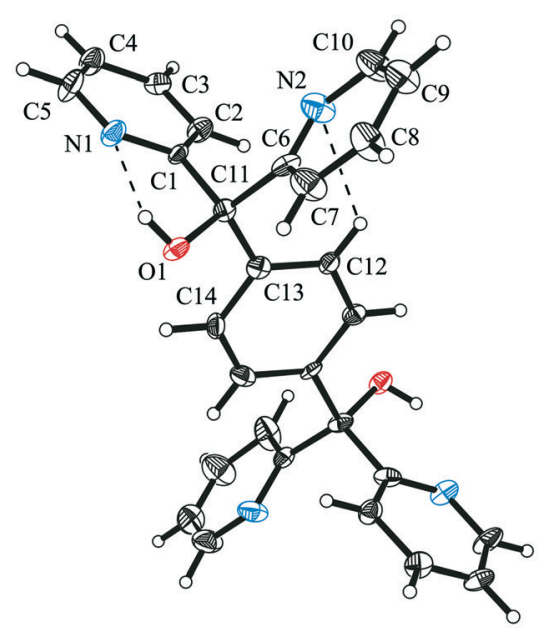

(c)

Fig. 2 Molecular structures of solvent-free compound 1 (a) and hostguest inclusion compounds $1 \mathrm{a}$ (b) and $1 \mathrm{~b}$ (c) shown as ellipsoid plots with $50 \%$ probability level.
Table 3 Torsion angles in the crystal structures of $1,1 a, 1 b, 2 a$, and $2 b$

\begin{tabular}{llll}
\hline Torsion angles $\left(^{\circ}\right)$ & $\mathbf{1}$ & $\mathbf{1 a}$ & $\mathbf{1 b}$ \\
\hline$\tau_{1}(\mathrm{~N} 1-\mathrm{C} 1-\mathrm{C} 11-\mathrm{O} 1)$ & $-6.24(2)$ & $-14.3(1)$ & $-22.9(1)$ \\
$\tau_{2}(\mathrm{~N} 2-\mathrm{C} 6-\mathrm{C} 11-\mathrm{O} 1)$ & $163.1(1)$ & $136.9(1)$ & $160.3(1)$ \\
$\tau_{3}(\mathrm{C} 14-\mathrm{C} 13-\mathrm{C} 11-\mathrm{O} 1)$ & $-31.7(2)$ & $-39.7(1)$ & $-37.7(1)$ \\
& & $2 \mathbf{a}$ & $2 \mathbf{b}$ \\
$\tau_{1}(\mathrm{~S} 1-\mathrm{C} 1-\mathrm{C} 9-\mathrm{O} 1)$ & & $-29.3(1)$ & $-21.2(3)$ \\
$\tau_{2}(\mathrm{~S} 2-\mathrm{C} 5-\mathrm{C} 9-\mathrm{O} 1)$ & & $-27.8(1)$ & $-32.6(3)$ \\
$\tau_{3}(\mathrm{C} 12-\mathrm{C} 10-\mathrm{C} 9-\mathrm{O} 1)$ & & $-58.7(2)$ & $-63.1(2)$ \\
\hline
\end{tabular}

with the dioxane oxygen O1G being in an inverse bifurcated connection (Fig. 7a). Furthermore, $\mathrm{C}-\mathrm{H} \cdots \pi$ interactions of the dioxane methylene groups $\mathrm{C} 1 \mathrm{G}-\mathrm{H} 1 \mathrm{G} 1[d(\mathrm{C} 1 \mathrm{G} \cdots \mathrm{Cg} 1)=$ $3.538(2) \AA]$ and $\mathrm{C} 2 \mathrm{G}-\mathrm{H} 2 \mathrm{G} 2[d(\mathrm{C} 2 \mathrm{G} \cdots \mathrm{Cg} 5)=3.511(2) \AA]$ with a thiophene ring exist in the structure. The packing index of 2a is $69.7 \%$, while the structure without a guest features a solvent accessible void of $155.3 \AA^{3}$ which equates to $23.9 \%$ of the unit cell. The corresponding solvent-free packing index was determined to be $57.5 \%$.

As contrasted with $2 \mathbf{a}$, the host molecules of $\mathbf{2 b}$ are connected in strands along the crystallographic $b$-axis by weak $\mathrm{C}-\mathrm{H} \cdots \mathrm{O}$ hydrogen bonds $[d(\mathrm{C} 4 \cdots \mathrm{O} 1)=3.460(2) \AA]$ and $\mathrm{C}-\mathrm{H} \cdots \pi$ contacts $[d(\mathrm{C} 3 \cdots \mathrm{Cg} 3)=3.814(2) \AA]$, while all further interactions exclusively involve host and guest molecules. Thus, a hydrogen bond ring motif with the graph set $\mathrm{R}_{4}^{4}(8)$ including the $\mathrm{OH}$ groups of two host molecules bridged by the NH functions of two pyrrolidine molecules is observed (Fig. 7b). In addition, $\mathrm{C}-\mathrm{H} \cdots \mathrm{N}$ contacts of the benzene methine group $\mathrm{C} 12-\mathrm{H} 12$ and the pyrrolidine nitrogen $\mathrm{N} 1 \mathrm{G}$ $[d(\mathrm{C} 12 \cdots \mathrm{N} 1 \mathrm{G})=3.464(2) \AA]$ as well as $\mathrm{C}-\mathrm{H}^{\cdots} \cdots \pi$ interactions of the pyrrolidine methylene group $\mathrm{C} 3 \mathrm{G}-\mathrm{H} 3 \mathrm{G} 1$ and the thiophene ring $\mathrm{Cg} 2[d(\mathrm{C} 3 \mathrm{G} \cdots \mathrm{Cg} 2)=3.714(2) \AA]$ stabilize the structure. Moreover, a methylene group of the pyrrolidine (C2GH2G1) forms a C-H $\cdots$ S contact ${ }^{32,43}$ with the thiophene sulfur S2 $[d(\mathrm{C} 2 \mathrm{G} \cdots \mathrm{S} 2)=3.729(2) \AA]$. Hence, in the packing structure, solvent channels $\left(c a .4 .2 \times 8.7 \AA^{2}\right)$ along the $a$-axis contain pyrrolidine guest molecules (Fig. 8b). A packing index (KPI) of $70.4 \%$ was determined for this structure. Removal of the guest from the structure offers a solvent accessible void of $472.5 \AA^{3}$ which equates to $32.0 \%$ of the unit cell and the corresponding packing index amounts to $50.4 \%$.

\section{Crystal structures of the polymorphs of compound 3}

According to our findings, compound 3 exclusively crystallizes solvent-free. But under different conditions, three polymorphs 3A-3C were obtained. Among them, polymorph 3A seems to be a very special case since it could be isolated only once, as a product batch of the synthesis of 3 after column chromatography, elution of the compound with ethyl acetate evaporation of the solvent and stirring with acetone yielded crystals of $3 \mathrm{~A}$ in the monoclinic space group $P 2_{1} / c$. Remarkably, we were unable to reproduce this result. By way of contrast, crystallization with cooling off and slow evaporation of 3 from solutions of EtOAc, $\mathrm{CHCl}_{3}$, pyridine, DMSO, DMF, acetone 
Table 4 Non-covalent interactions in the crystal structures of 1, 1a and $1 \mathrm{~b}$

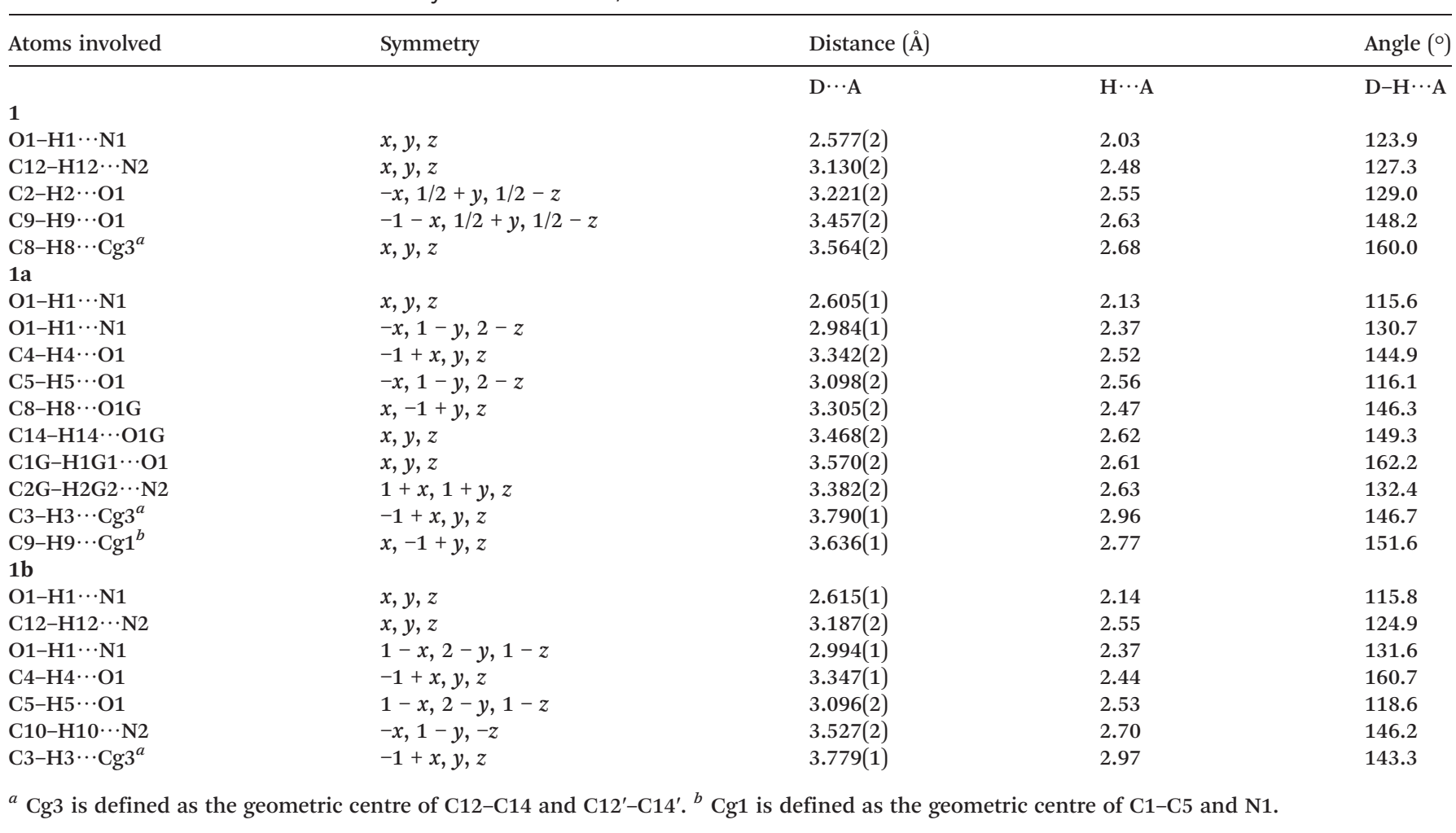

and $n-\mathrm{BuOH}$, respectively, gave crystals of polymorph $3 \mathbf{B}$ in the triclinic space group $P \overline{1}$, while polymorph $3 \mathrm{C}$ crystallized from 1,4-dioxane in the space group as before.

In the cases of $\mathbf{3 A}$ and $\mathbf{3 B}$, the asymmetric part of the unit cell contains one diol molecule, whereas in $3 \mathrm{C}$ two independent diol molecules differing in the conformation and being also different from 3A are included (Fig. 9). This becomes apparent by the overlay of the central benzene unit and the tertiary $\mathrm{sp}^{3}$ carbon atoms in Fig. 10. While the oxygen atoms of $3 \mathrm{~B}$ and $3 \mathrm{C}$ are nearly located within the benzene plane, the pyridine rings point away from the benzene plane (Fig. 10b). Moreover, the conformation of 3B is almost identical to that of molecule 2 of $3 \mathrm{C}$, whereas molecule 1 of $3 \mathrm{C}$ features slightly twisted pyridine rings of which two pyridine nitrogens are in opposite orientation compared with molecule 2 of 3C. By way of contrast, the oxygen atoms of $3 \mathrm{~A}$ are arranged out of the benzene plane in opposite directions, while two pyridine rings are nearly aligned to the benzene plane and the other two rings are almost vertical (Fig. 10a).

A more detailed conformational comparison involving the torsion angles of the aromatic units with reference to the hydroxyl groups shows that corresponding values of the pyridine rings $\left(-167.4^{\circ}\right.$ to $\left.161.9^{\circ}\right)$ are in a much broader range than the values of the benzene rings $\left(-15.8^{\circ}\right.$ to $\left.39.3^{\circ}\right)$ (Table 6). Furthermore, the high conformational similarity between 3B and molecule 2 of $3 \mathrm{C}$ is confirmed by the torsion angles that are almost identical. Actually, the molecular conformations of all three polymorphs are stabilized by intramolecular $\mathrm{O}-\mathrm{H} \cdots \mathrm{N}$ and $\mathrm{C}-\mathrm{H} \cdots \mathrm{N}$ hydrogen bonding contacts including pyridine nitrogens and hydroxyl functions or benzene methine groups, respectively. The non-covalent interactions of the polymorphs of 3 are summarized in Table 7.

The packing structure of polymorph $3 \mathrm{~A}$ consists of molecular dimers connected by a hydrogen bond ring motif with the graph set $\mathrm{R}_{2}^{2}(10)$ including $\mathrm{O}-\mathrm{H} \cdots \mathrm{N}$ contacts $[d(\mathrm{O} 1 \cdots \mathrm{N} 1)=$ $3.031 \AA]$, which is shown in Fig. 11a. Along the crystallographic $a$-axis, the dimers are arranged in strands stabilized by weak $\mathrm{C}-\mathrm{H} \cdots \mathrm{O}$ contacts $[d(\mathrm{C} 9 \cdots \mathrm{O} 1)=3.515 \AA$ and $d(\mathrm{C} 17 \cdots \mathrm{O} 2)=3.419 \AA]$. In the direction of the $b$-axis, the strands are also linked by $\mathrm{C}-\mathrm{H} \cdots \mathrm{O}$ interactions $[d(\mathrm{C} 4 \cdots \mathrm{O} 1)=$ $3.399 \AA$ and $d(\mathrm{C} 22 \cdots \mathrm{O} 2)=3.307 \AA]$ and in addition to that via $\mathrm{C}-\mathrm{H} \cdots \pi$ contacts $[d(\mathrm{C} 3 \cdots \mathrm{Cg} 5)=3.774 \AA$ A $]$ with the oxygen atom $\mathrm{O} 1$ being in an inverse trifurcated connection and $\mathrm{O} 2$ in an inverse bifurcated connection. Along the $c$-axis, only $\mathrm{C}-\mathrm{H} \cdots \pi$ interactions $[d(\mathrm{C} 26 \cdots \mathrm{Cg} 4)=3.805 \AA]$ exist between the strands.

As contrasted with $3 \mathrm{~A}$, the packing structures of polymorphs 3B and 3C are arranged in a chain-like connection mode of the diol molecules (Fig. 11b and c). They are alternately linked by the already mentioned hydrogen bond ring motif $\mathbf{R}_{2}^{2}(10)$ consisting of $\mathrm{O}-\mathrm{H} \cdots \mathrm{N}$ interactions $[d(\mathrm{O} 1 \cdots \mathrm{N} 1)=$ $2.822(2) \AA(3 \mathrm{~B}), d(\mathrm{O} 1 \cdots \mathrm{N} 5)=2.817(4) \AA$ and $d(\mathrm{O} 3 \cdots \mathrm{N} 2)=$ $2.810(4) \AA$ (3C)] and by a ring motif with the graph set $\mathrm{R}_{2}^{2}(6)$ involving $\mathrm{C}-\mathrm{H} \cdots \mathrm{N}$ contacts $[d(\mathrm{C} 23 \cdots \mathrm{N} 3)=3.448(2) \AA(3 \mathrm{~B})$, $d(\mathrm{C} 28 \cdots \mathrm{N} 4)=3.463(5) \AA$ and $d(\mathrm{C} 51 \cdots \mathrm{N} 7)=3.429(5) \AA(3 \mathrm{C})]$. Due to the existence of two independent conformations in the structure of $3 \mathrm{C}$, the diol chains feature an alternation of the set of independent conformations. In this case, molecules 
(a)

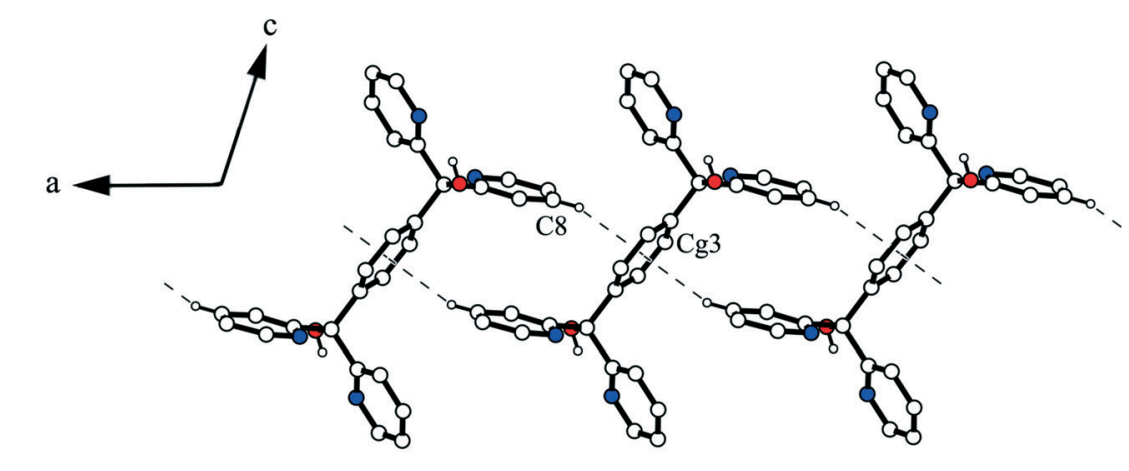

of the same conformation are connected by the above specified $\mathrm{C}-\mathrm{H} \cdots \mathrm{N}$ contacts, while those possessing different conformations are linked by the $\mathrm{O}-\mathrm{H} \cdots \mathrm{N}$ interactions. Superimposed molecular chains are stabilized in the direction of the $a$-axis by $\mathrm{C}-\mathrm{H} \cdots \mathrm{O}[d(\mathrm{C} 17 \cdots \mathrm{O} 2)=3.466 \AA(3 \mathrm{~B})$ and $d(\mathrm{C} 22 \cdots \mathrm{O} 4)=3.447 \AA(3 \mathrm{C})]$ and $\mathrm{C}-\mathrm{H} \cdots \pi$ contacts $[d(\mathrm{C} 5 \cdots \mathrm{Cg} 6)=$ $3.701 \AA(3 \mathrm{~B})$ and $d(\mathrm{C} 33 \cdots \mathrm{Cg} 14)=3.693 \AA(3 \mathrm{C})]$ as well as by $\pi \cdots \pi$ interactions between pyridine rings. Along the [111]-direction, the chains are linked by weak $\mathrm{C}-\mathrm{H} \cdots \mathrm{O}$ hydrogen bonds $[d(\mathrm{C} 28 \cdots \mathrm{O} 1)=3.426 \AA(3 \mathrm{~B}), d(\mathrm{C} 56 \cdots \mathrm{O} 3)=3.421 \AA$ and $d(\mathrm{C} 23 \cdots \mathrm{O} 1)=3.420 \AA$ (3C)], while additional $\mathrm{C}-\mathrm{H} \cdots \pi$ contacts $[d(\mathrm{C} 4 \cdots \mathrm{Cg} 13)=3.641 \AA$ and $d(\mathrm{C} 37 \cdots \mathrm{Cg} 12)=3.671 \AA]$ exist in $3 \mathrm{C}$.

Considering the thermal behavior of $\mathbf{3 A}-\mathbf{3 C}$, it is obvious that polymorph $3 \mathrm{~A}$ is the one that melts at the lowest temperature, i.e. from 187 to $189{ }^{\circ} \mathrm{C}$, while 3B and 3C melt between 196 and $199^{\circ} \mathrm{C}$. More detailed investigation with reference to 3B (Sup. 1) and 3C (Sup. 2) has been performed by differential scanning calorimetry (DSC). Here, onset temperatures for melting of $198.6^{\circ} \mathrm{C}(3 \mathrm{~B})$ and $197.6^{\circ} \mathrm{C}(3 \mathrm{C})$ as well as enthalpy values for the melting process of $46.8 \mathrm{~kJ} \mathrm{~mol}^{-1}$ (3B) and 46.0 $\mathrm{kJ} \mathrm{mol}^{-1}$ (3C) have been determined. Actually a difference in melting temperature of $1 \mathrm{~K}$ regarding $3 \mathrm{~B}$ and $3 \mathrm{C}$ is only small, nevertheless in a way significant since it correlates with the close relationship between the two crystal structures. Furthermore, one may conclude from the melting data that 3B is the most stable species in the series of the present polymorphs followed by $\mathbf{3 C}$ and $\mathbf{3 A}$. To a certain extent, this is perhaps in line with the preferred result of the chemical preparation of 3, normally leading to $3 \mathbf{B}$. The DSC diagrams are included in the ESI $\uparrow$ as Sup. 1 and Sup. 2.

\section{Sorption behavior}

Apart from the static inclusion of guest molecules realized by crystallization, which has been discussed above, the dynamic sorption properties of host compounds are particularly interesting for application as mass sensitive sensor materials. ${ }^{28,44}$ Previous investigation along this line based on sorption behavior studies by QCM measurements ${ }^{45}$ has been carried 


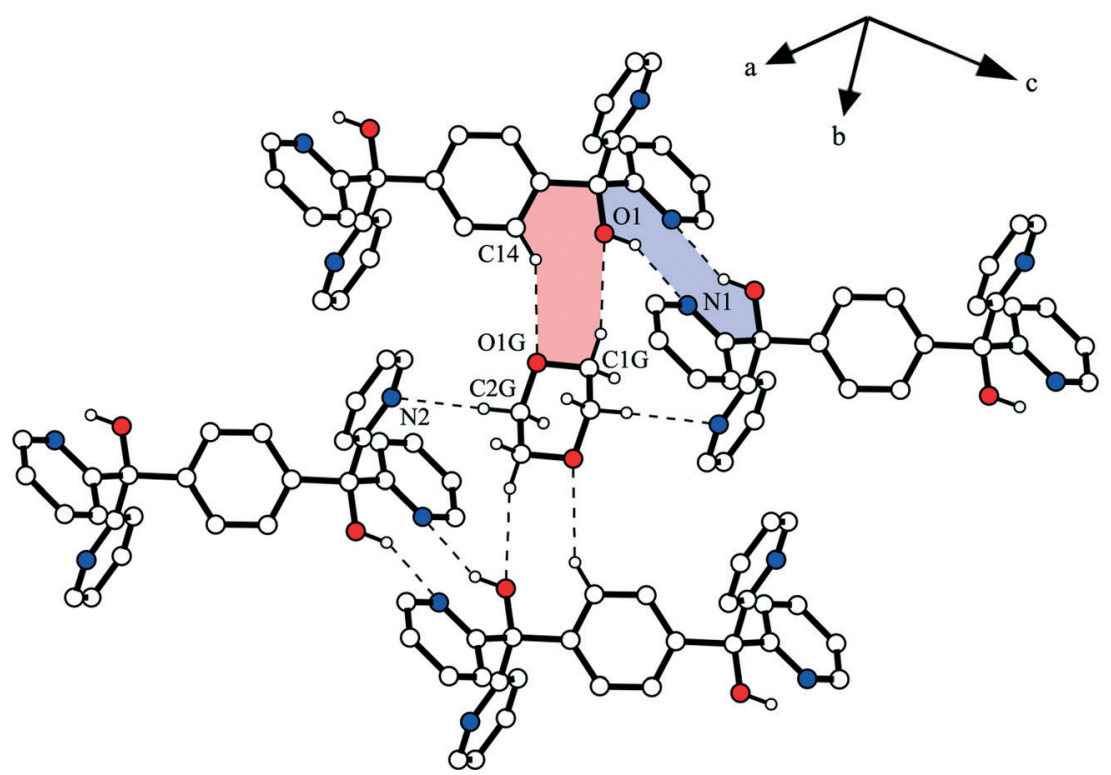

Fig. 4 Interactions of the 1,4-dioxane molecule in the structure of 1 a. The hydrogen bond ring motifs $R_{2}^{2}(8)$ and $R_{2}^{2}(10)$ are highlighted. Nonrelevant $\mathrm{H}$ atoms are omitted for clarity.
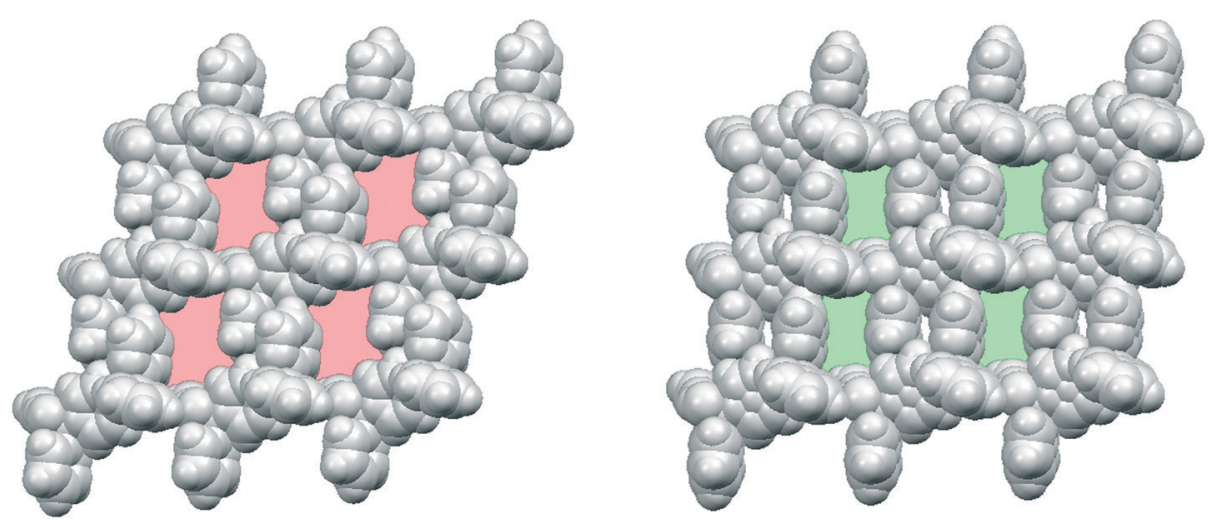

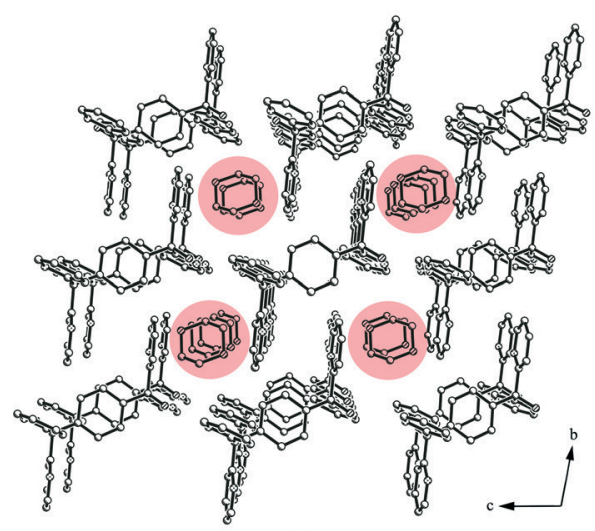

(a)

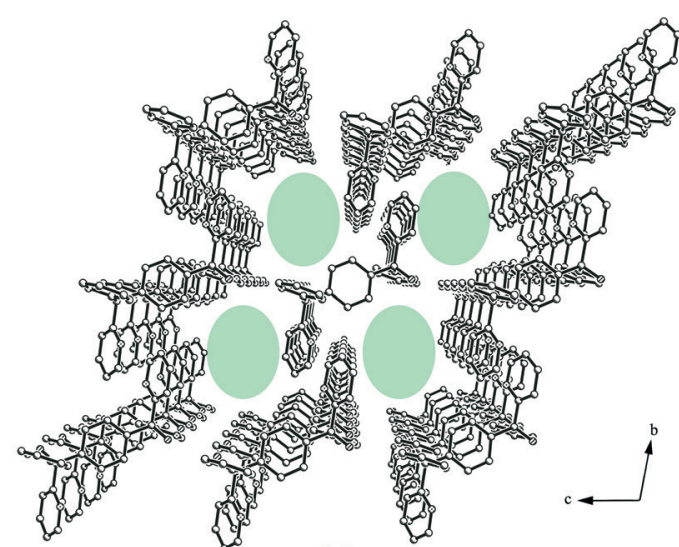

(b)

Fig. 5 Packing structure and van der Waals models (without guests) of the 1:1 1,4-dioxane inclusion compound 1a (a) and the 1:2 toluene inclusion compound $1 \mathrm{~b}$ (b). The solvent channels along the $\mathrm{a}$-axis are highlighted. All $\mathrm{H}$ atoms of the packing structures were omitted for clarity.

out for other potential host compounds. ${ }^{46-50}$ Being deduced from it, a solvent-free host coating should be able to interact with gaseous guest molecules yielding a temporary inclusion compound. In order to investigate potential sorptive guest 


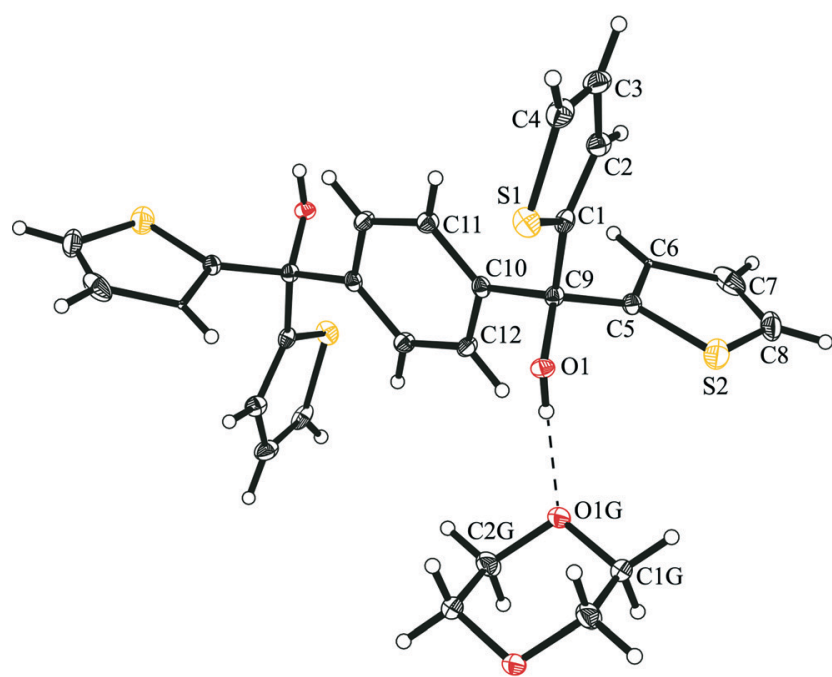

(a)

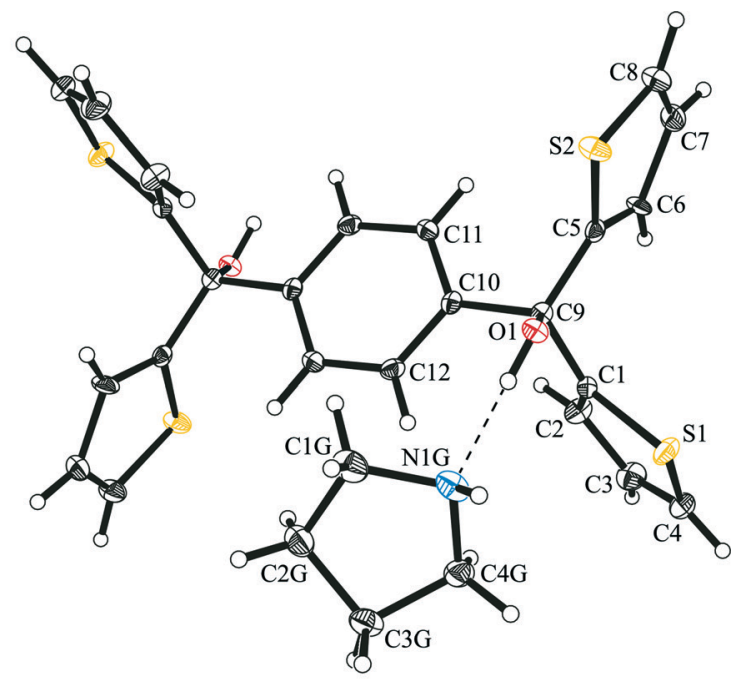

(b)

Fig. 6 Molecular structures of (a) 1,4-dioxane (2a) and (b) pyrrolidine (2b) host-guest inclusion compounds of 2 shown as ellipsoid plots with $50 \%$ probability level.

selectivity of the present compounds, different solvents representing varied polarity properties with protic as well as aprotic characteristics (Fig. 12) were used (n-hexane, $\mathrm{CHCl}_{3}$, $\mathrm{THF}$, acetone, EtOH and $\mathrm{Et}_{2} \mathrm{NH}$ ). One may expect that the rather limited inclusion ability of $\mathbf{1}$ and 2 derived from the above crystallization studies, but on the other hand indicating distinct selectivity, could also be reflected in the results of sorption measurements. On parallel testing of 1 and 2 towards different solvents, the thiophene containing host 2, in particular, behaves remarkably, clearly featuring a selective sorption of $\mathrm{THF}(84 \%)$ and $\mathrm{Et}_{2} \mathrm{NH}(108 \%, c a .1: 1$ stoichiometry), while the other solvents were adsorbed only in amounts below $50 \%$. Here, the sorption of $\mathrm{Et}_{2} \mathrm{NH}$ is a notable finding since formation of an inclusion compound with $\mathrm{Et}_{2} \mathrm{NH}$ was not observed under crystallization conditions, possibly due to the lack of a stable packing arrangement. But sorption of the amine from the gas phase seems to be definitely preferred probably owing to the formation of strong $\mathrm{O}-\mathrm{H} \cdots \mathrm{N}$ and $\mathrm{N}-$ $\mathrm{H} \cdots \mathrm{O}$ interactions between the host hydroxyl and the guest amine functions. By way of contrast, the pyridine containing diol 1 shows a selective sorption of EtOH (73\%), while the other solvents were adsorbed only below the index of $50 \%$. An explanation for this remarkable behavior could be the formation of strong intramolecular hydrogen bonds ( $c f$. crystal structure of unsolvated 1) preventing intermolecular H-donor properties of the host hydroxyl groups in hydrogen bonding to guests. Hence, $\mathbf{1}$ is only available as a $\mathrm{H}$-acceptor in hydrogen bonding to active $\mathrm{H}$-donor guest molecules such as EtOH. Following this point of view, protic $\mathrm{Et}_{2} \mathrm{NH}$ should also be a suitable candidate for binding to 1 . However, contrary to expectation, $\mathrm{Et}_{2} \mathrm{NH}$ is not absorbed as compared to $\mathrm{EtOH}$. Here, steric hindrance between the host and the rather bulky $\mathrm{Et}_{2} \mathrm{NH}$ molecule may account for this specific restriction. Moreover, it is very obvious from the diagram in Fig. 12 that both the aprotic solvents $\mathrm{CHCl}_{3}$ and $n$-hexane are distinctly less absorbed using 1 as well as 2 , being in conformity with the above conception of host-guest hydrogen bonding.

\section{Comparative discussion and conclusion}

Nuclear addition reactions of 2-pyridyllithium, 3-pyridyllithium or 2-thienyllithium to corresponding diacid dichlorides ( 1 and 3 ) or the corresponding diester (2) successfully gave new diol compounds 1-3 in moderate to high yields. Based on the heteroaromatic (pyridyl, thienyl) moieties substituting the phenyl residues of the model wheel-and-axle host molecule $(\mathbf{P h})$, they represent examples of a new structural modification of this particular host type featuring further potential receptor sites for hydrogen bonding (pyridyl) or other interaction modes emanating from the thienyl groups. However, X-ray structures involving pyridyl-containing 1 and 3 both in solvent-free and solvent-complexed forms show that the hydroxy groups are intramolecularly coordinated to pyridyl moieties which is restrictive to polar solvent interaction, while thiophene derivative 2 is not subjected to a corresponding behavior. This is clearly expressed by the number and variety of crystalline solvent inclusions obtained from 1 and 2 demonstrating that $\mathbf{1}$ has a much lower capability to include solvents than 2, being restraint only to the apolar solvent molecules 1,4-dioxane and toluene under the conditions of this study. Nevertheless, the host molecule 2, having a moderately broad inclusion behavior, is distinctly inferior in forming crystalline solvent inclusions to the prototype host compound Ph. Reflecting on a comparison between solvent inclusions of Ph and 2, there are a few rather close similarities, e.g. inclusion of both with acetone and toluene. But Ph failed in solvent inclusion with alcohols, while 2 proved its activity in this respect. Thus, on the one hand, both 1 and 2 can be seen as 


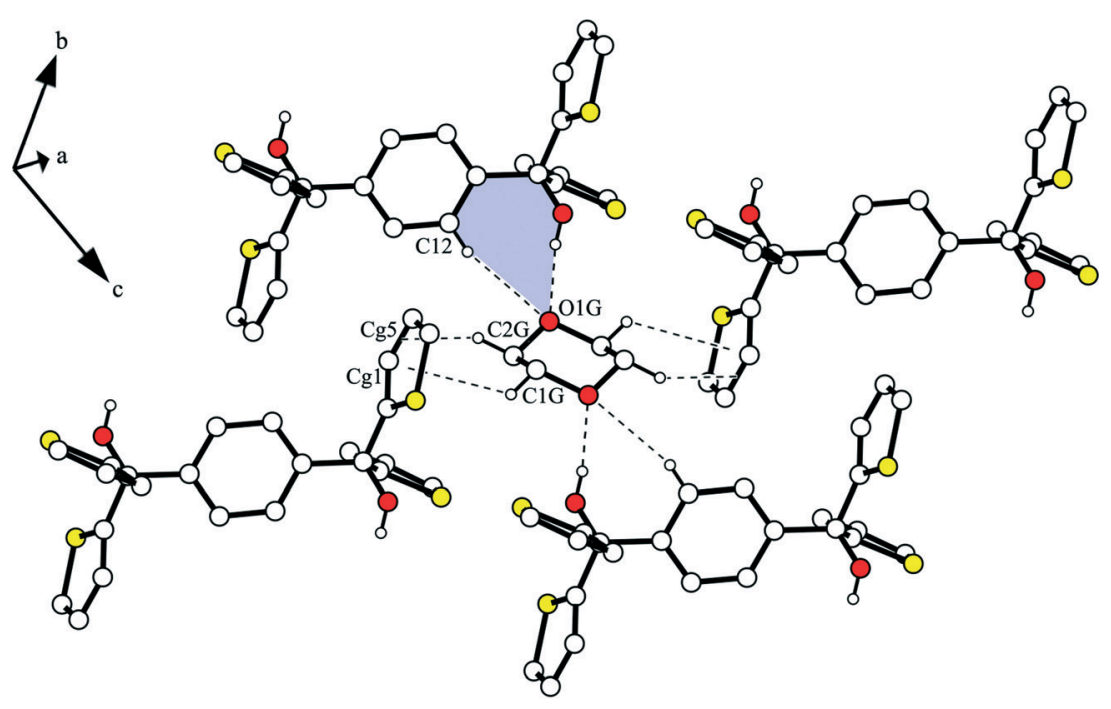

(a)

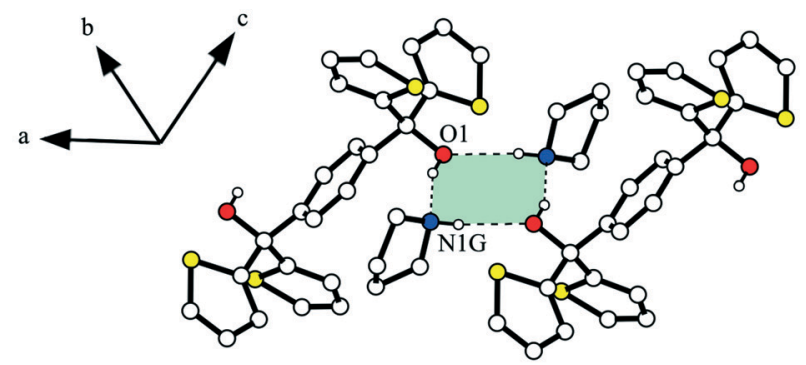

(b)

Fig. 7 (a) Connection of the 1,4-dioxane guest in inclusion compound $2 \mathrm{a}$ by $\mathrm{O}-\mathrm{H} \cdots \mathrm{O}$ and $\mathrm{C}-\mathrm{H} \cdots \mathrm{O}$ hydrogen bonds as well as $\mathrm{C}-\mathrm{H} \cdots \pi$ interactions. The hydrogen bond ring motif $\mathrm{R}_{2}^{1}(7)$ is highlighted. (b) Connection mode of the host molecules of $2 \mathrm{~b}$ by the highlighted hydrogen bond ring motif $\mathrm{R}_{4}^{4}(8)$ involving two pyrrolidine molecules. Non-relevant $\mathrm{H}$ atoms are omitted for clarity.

hosts inferior to $\mathbf{P h}$ in a multitude of solvent inclusions, but it seems that they are superior to $\mathbf{P h}$ in the selectivity of inclusion formation which, however, requires support from a more detailed study including competition of solvents. Remarkably, the 1,3-substituted pyridino derivative at the axle position (3) is found incapable of solvent inclusion pointing out that straightness of the axle moiety is the whole point of the host structure. Yet one has the impression that the packing of 3 is not a definite case allowing the formation of at least three polymorphs on crystallization from different solvents, unlike 1 that also crystallizes in a solvent-free form. By way of contrast, in the solvent inclusions of 1 and 2, the host-guest connectivity is caused by a variety of weak C$\mathrm{H} \cdots \mathrm{N}$ and $\mathrm{C}-\mathrm{H} \cdots \mathrm{O}$ contacts as well as strong $\mathrm{O}-\mathrm{H} \cdots \mathrm{N}$ and $\mathrm{O}-\mathrm{H} \cdots \mathrm{O}$ hydrogen bonds giving rise to noticeable ring motifs.

Furthermore, sorption experiments applying a quartz crystal microbalance coated with solid films of $\mathbf{1}$ and 2 proved efficient in the selective uptake of solvent vapors considering a variety of apolar to polar solvents that should offer a promising possibility for sensor development. However, the results of this study also make us aware that the vapor sorption behavior and solvent co-crystallization properties of the present hosts are only limitedly transferable. As a matter of fact, due to the different modes of inclusion formation, this difference appears evident.

\section{Experimental}

\section{General remarks}

The melting points were measured using a microscope heating stage (Thermovar, Reichert-Jung). IR spectra were recorded on a Nicolet FT-IR 510 spectrometer as KBr pellets (wavenumbers given in $\mathrm{cm}^{-1}$ ). ${ }^{1} \mathrm{H}$ and ${ }^{13} \mathrm{C}$ NMR spectra were obtained using a Bruker Avance 500 at $500.1\left({ }^{1} \mathrm{H}\right)$ and 125.8 $\mathrm{MHz}\left({ }^{13} \mathrm{C}\right)$ with TMS as internal standard. Chemical shifts for proton and carbon resonances are given in ppm $(\delta)$. Mass spectra were recorded on a Hewlett Packard 5890 Series II/MS 5971 A. DSC measurements were executed using a Sensys 
Table 5 Intermolecular interactions in the crystal structures of $\mathbf{2 a}$ and $\mathbf{2 b}$

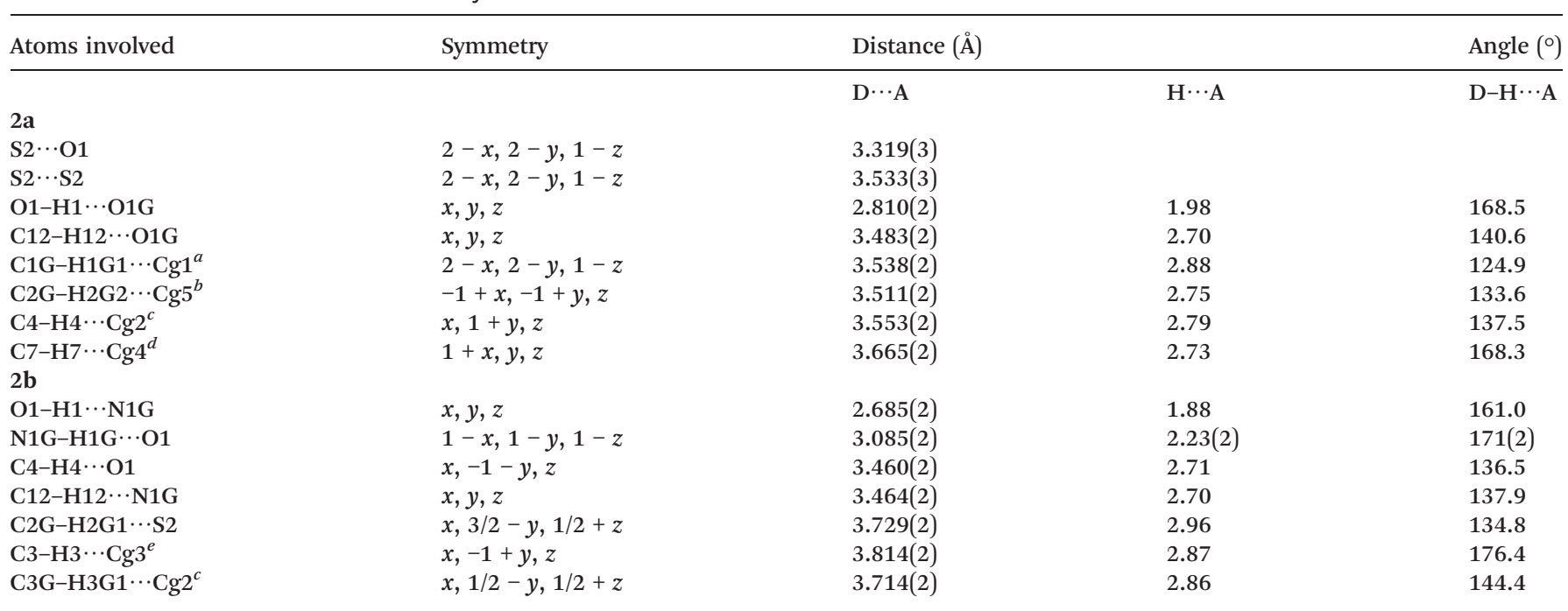

${ }^{a} \mathrm{Cg} 1$ is defined as the geometric centre of $\mathrm{C} 1-\mathrm{C} 4$ and $\mathrm{S} 1 .^{b} \mathrm{Cg} 5$ is defined as the geometric centre of $\mathrm{C} 2-\mathrm{C} 3{ }^{c} \mathrm{Cg} 2$ is defined as the geometric centre of $\mathrm{C} 5-\mathrm{C} 8$ and S2. ${ }^{d} \mathrm{Cg} 4$ is defined as the geometric centre of $\mathrm{C} 10-\mathrm{C} 11 .{ }^{e} \mathrm{Cg} 3$ is defined as the geometric centre of $\mathrm{C} 10-\mathrm{C} 12$ and $\mathrm{C} 10^{\prime}-$ C12'.
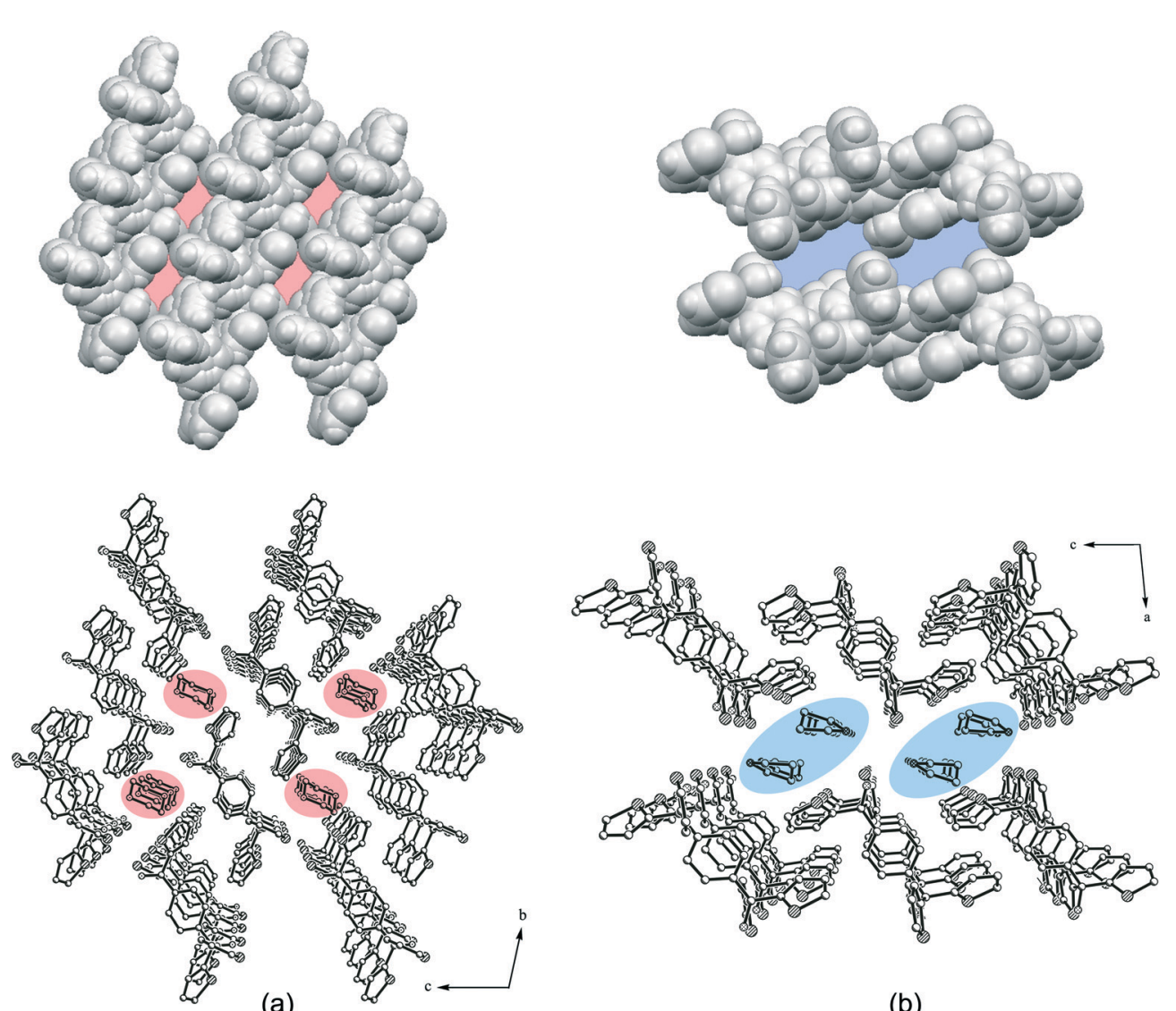

(b)

Fig. 8 Packing structure and van der Waals models (without guests) of the 1:1 dioxane inclusion compound 2a (a) and the 1:2 pyrrolidine inclusion compound $\mathbf{2 b}(\mathrm{b})$. The solvent channels along the $\mathrm{a}$-axis are highlighted. All $\mathrm{H}$ atoms of the packing structures were omitted for clarity.

TGA DSC (Setaram). TLC analysis was performed using aluminium sheets precoated with silica gel $60 \mathrm{~F}_{254}$ (Merck). Silica gel (63-100 $\mu \mathrm{m}$, Merck) was used for column chromatography. Solvents were purified by standard procedures.

\section{Syntheses of diols 1-3}

1,4-Bis[di(pyrid-2-yl)hydroxymethyl]benzene (1). To a mixture of 2-bromopyridine $(1.96 \mathrm{~g}, 12.4 \mathrm{mmol})$ in $10 \mathrm{ml}$ of dry 

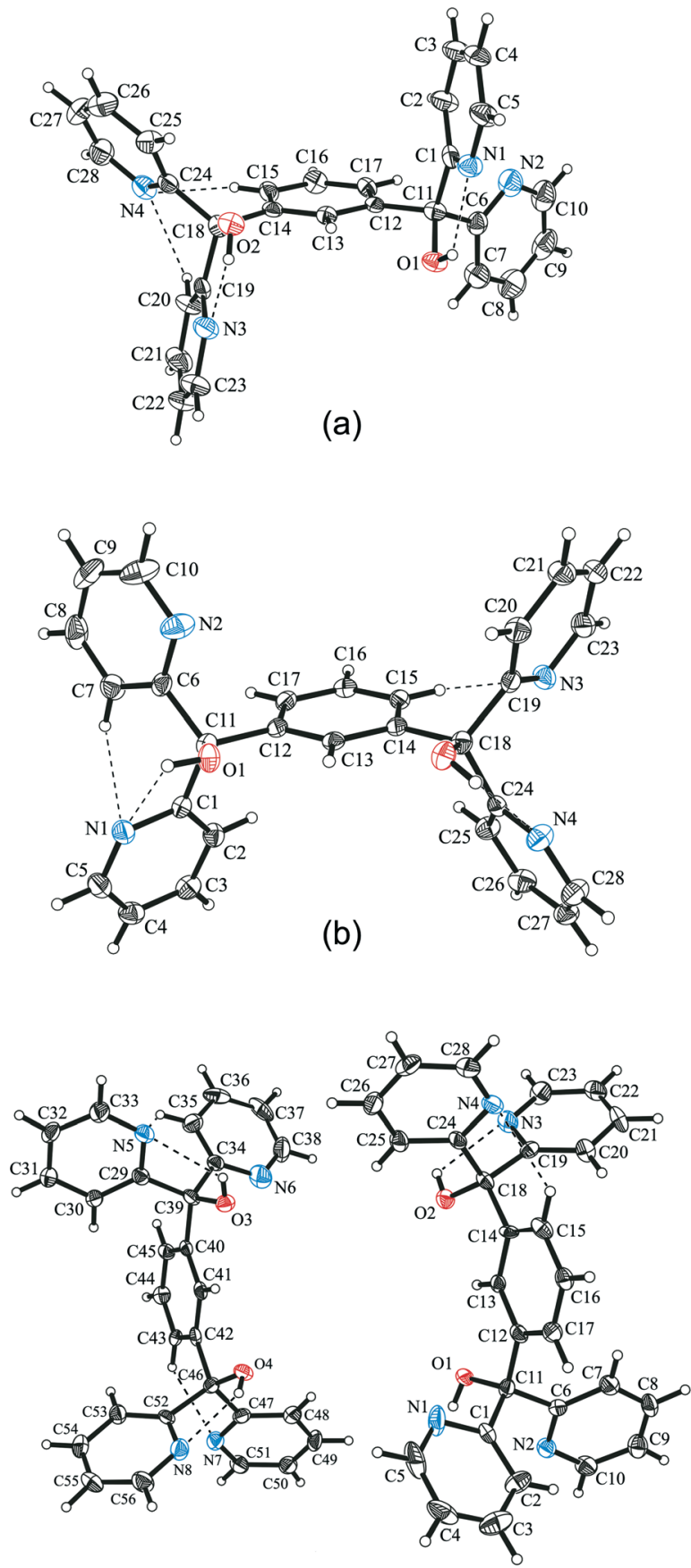

(c)

Fig. 9 Molecular structures of polymorphs 3A (a), 3B (b) and 3C (c) shown as ellipsoid plots with $50 \%$ probability level.

THF, cooled to $-78{ }^{\circ} \mathrm{C}$ under argon, $n$-BuLi $(7.8 \mathrm{ml}, 12.4$ mmol, 1.6 $\mathrm{M}$ in $n$-hexane) was added slowly via a syringe. After stirring the solution for $15 \mathrm{~min}$ at $-78{ }^{\circ} \mathrm{C}$, terephthaloyl chloride $(0.63 \mathrm{~g}, 3.1 \mathrm{mmol})$ dissolved in $10 \mathrm{ml}$ of dry THF was added dropwise. The resulting mixture was stirred for $1 \mathrm{~h}$ at $-78^{\circ} \mathrm{C}$, then for $3 \mathrm{~h}$ at room temperature and after that hydrolyzed with sat. $\mathrm{NH}_{4} \mathrm{Cl}$ solution. The mixture was extracted with $\mathrm{CH}_{2} \mathrm{Cl}_{2}(3 \times 20 \mathrm{ml})$, the organic phase dried $\left(\mathrm{Na}_{2} \mathrm{SO}_{4}\right)$ and the solvent evaporated. The obtained brown oil

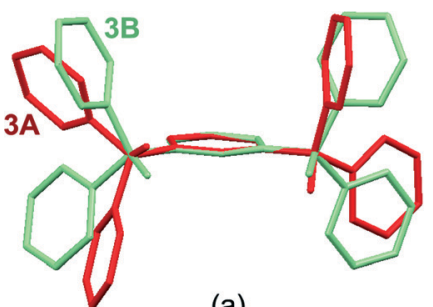

(a)

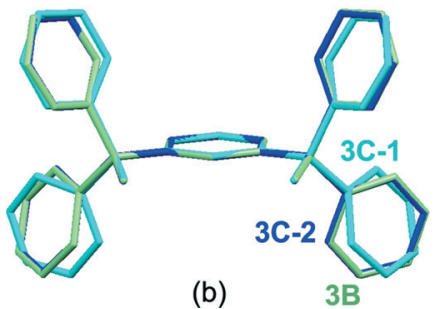

Fig. 10 Overlay of the molecular conformations: (a) $3 \mathrm{~A}$ and 3B, and (b) 3B and 3C (molecules 1 and 2).

was treated under stirring for $20 \mathrm{~min}$ in $10 \mathrm{ml}$ of acetone to give a precipitate which was separated and dried yielding compound 1 as a beige solid $(0.51 \mathrm{~g}, 57 \%)$. Mp $229-232{ }^{\circ} \mathrm{C}$ (from acetone). NMR data: $\delta_{\mathrm{H}}\left(500.1 \mathrm{MHz}, \mathrm{CDCl}_{3}, \mathrm{TMS}\right) 6.87$ $(2 \mathrm{H}, \mathrm{s}, \mathrm{OH}), 7.16\left(4 \mathrm{H}, \mathrm{td}, \mathrm{PyH}_{5}, J_{\mathrm{HH}}=4.90,0.90 \mathrm{~Hz}\right), 7.22$ $(4 \mathrm{H}, \mathrm{s}, \mathrm{Ph}), 7.65\left(4 \mathrm{H}, \mathrm{td}, \mathrm{PyH}_{4}, J_{\mathrm{HH}}=7.65,1.75 \mathrm{~Hz}\right), 7.76(4 \mathrm{H}$, $\left.\mathrm{d}, \mathrm{PyH}_{3}, J_{\mathrm{HH}}=7.95 \mathrm{~Hz}\right), 8.49\left(4 \mathrm{H}, \mathrm{d}, \mathrm{PyH}_{6}, J_{\mathrm{HH}}=8.05 \mathrm{~Hz}\right) . \delta_{\mathrm{C}}$ (125.8 MHz, $\left.\mathrm{CDCl}_{3}\right)$ 80.2 (C-OH), $122.2\left(\mathrm{PyC}_{5}\right), 123.2\left(\mathrm{PyC}_{3}\right)$, $127.5(\mathrm{Ph}), 136.4\left(\mathrm{PyC}_{4}\right), 145.0(\mathrm{Ph}), 147.3\left(\mathrm{PyC}_{6}\right), 163.0$ $\left(\mathrm{PyC}_{2}\right)$. IR data: $v_{\max } 3278 \mathrm{~m}(\mathrm{OH}, \mathrm{br}), 3056 \mathrm{w}$ and $3003 \mathrm{w}$ $\left(\mathrm{CH}_{\mathrm{Ar}}\right), 1739 \mathrm{w}, 1717 \mathrm{w}, 1584 \mathrm{~s}$ and $1572 \mathrm{~m}(\mathrm{C}=\mathrm{C}), 1464 \mathrm{~s}$ $(\mathrm{C}=\mathrm{N}), 1432 \mathrm{~s}$ and $1410 \mathrm{~s}(\mathrm{OH}), 1388 \mathrm{~m}, 1299 \mathrm{w}, 1283 \mathrm{w}, 1249 \mathrm{w}$, $1185 \mathrm{w}, 1150 \mathrm{w}, 1128 \mathrm{w}, 1100 \mathrm{w}, 1068 \mathrm{~m}$ and $1052 \mathrm{~m}$ (C-O), $1021 \mathrm{~m}, 995 \mathrm{~m}, 964 \mathrm{w}, 926 \mathrm{w}, 891 \mathrm{w}, 831 \mathrm{w}, 767 \mathrm{~s}$ and 748s $(\mathrm{CH})$, $707 \mathrm{~m}, 672 \mathrm{~m}(\mathrm{OH}), 618 \mathrm{w}, 599 \mathrm{w}, 565 \mathrm{w}, 542 \mathrm{w}, 517 \mathrm{w}$. MS data (ESI): calc. for $\mathrm{C}_{28} \mathrm{H}_{22} \mathrm{~N}_{4} \mathrm{O}_{2}$ (446.17), found: $447.0 \mathrm{~m} / \mathrm{z}[\mathrm{M}+$ $\mathrm{H}]^{+}$. Anal. calc. for $\mathrm{C}_{28} \mathrm{H}_{22} \mathrm{~N}_{4} \mathrm{O}_{2}$ : C, 75.32; H, 4.97; N, 12.55, found: C, 75.49; H, 4.96; N, 12.30\%.

1,4-Bis[di(thien-2-yl)hydroxymethyl]benzene (2). The synthesis follows a described procedure. ${ }^{29}$ To a mixture of thiophene $(1.75 \mathrm{~g}, 20.8 \mathrm{mmol})$ in $20 \mathrm{ml}$ of dry THF, cooled to -30 ${ }^{\circ} \mathrm{C}$ under argon, $n$-BuLi $(13.0 \mathrm{ml}, 20.8 \mathrm{mmol}, 1.6 \mathrm{M}$ in $n$-hexane) was added slowly via a syringe. After stirring the solution for $15 \mathrm{~min}$ at $-30^{\circ} \mathrm{C}$, dimethyl terephthalate $(0.82 \mathrm{~g}$, $4.2 \mathrm{mmol}$ ) dissolved in $20 \mathrm{ml}$ of dry THF was added dropwise. The resulting mixture was allowed to warm to room temperature and after that hydrolyzed with sat. $\mathrm{NH}_{4} \mathrm{Cl}$ solution. The mixture was extracted with $\mathrm{CH}_{2} \mathrm{Cl}_{2}(3 \times 30 \mathrm{ml})$, the organic phase dried $\left(\mathrm{Na}_{2} \mathrm{SO}_{4}\right)$ and the solvent evaporated. The residue was purified by chromatography on silica gel (EtOAc/ $n$-hexane, $\left.R_{\mathrm{f}}: 0.78\right)$ to yield 2 as a white solid (1.42 g, 98\%). Mp 155-158 ${ }^{\circ} \mathrm{C}$ (from acetone). NMR data: $\delta_{\mathrm{H}}(500.1$ $\left.\mathrm{MHz}, \mathrm{CDCl}_{3}, \mathrm{TMS}\right) 3.18(2 \mathrm{H}, \mathrm{s}, \mathrm{OH}), 6.84\left(4 \mathrm{H}, \mathrm{dd}, \mathrm{ThH}_{3}, J_{\mathrm{HH}}=\right.$ $3.52,1.00 \mathrm{~Hz}), 6.94\left(4 \mathrm{H}, \mathrm{m}, \mathrm{ThH}_{4}\right), 7.27\left(4 \mathrm{H}, \mathrm{dd}, \mathrm{ThH}_{5}, J_{\mathrm{HH}}=\right.$ $5.08,1.03 \mathrm{~Hz}), 7.43(4 \mathrm{H}, \mathrm{s}, \mathrm{Ph}) . \delta_{\mathrm{C}}\left(125.8 \mathrm{MHz} \mathrm{CDCl}_{3}\right) 77.8$ (C-OH), $125.8\left(\mathrm{ThC}_{3}\right), 126.3\left(\mathrm{ThC}_{5}\right), 126.6,145.5(\mathrm{Ph}), 151.6$ 
Table 6 Torsion angles of the molecular conformations of 3A, 3B and 3C

\begin{tabular}{lllll}
\hline Torsion angle $\left({ }^{\circ}\right)$ & $3 A$ & $3 B$ & $3 C$ (molecule 1) & 3C (molecule 2) \\
\hline$\tau_{1}(\mathrm{~N} 1-\mathrm{C} 1-\mathrm{C} 11-\mathrm{O} 1)$ & $9.3(4)$ & $51.6(2)$ & $-53.8(4)$ & $51.6(4)(\mathrm{N} 5-\mathrm{C} 29-\mathrm{C} 39-\mathrm{O} 3)$ \\
$\tau_{2}(\mathrm{~N} 2-\mathrm{C} 6-\mathrm{C} 11-\mathrm{O} 1)$ & $-139.3(3)$ & $53.8(2)$ & $-52.1(4)$ & $53.5(4)(\mathrm{N} 6-\mathrm{C} 34-\mathrm{C} 39-\mathrm{O} 3)$ \\
$\tau_{3}(\mathrm{C} 13-\mathrm{C} 12-\mathrm{C} 11-\mathrm{O} 1)$ & $39.3(4)$ & $14.9(2)$ & $-14.0(5)$ & $15.9(5)(\mathrm{C} 41-\mathrm{C} 40-\mathrm{C} 39-\mathrm{O} 3)$ \\
$\tau_{4}(\mathrm{~N} 3-\mathrm{C} 19-\mathrm{C} 18-\mathrm{O} 2)$ & $-2.8(4)$ & $161.4(1)$ & $37.4(4)$ & $161.9(3)(\mathrm{N} 7-\mathrm{C} 47-\mathrm{C} 46-\mathrm{O} 4)$ \\
$\tau_{5}(\mathrm{~N} 4-\mathrm{C} 24-\mathrm{C} 18-\mathrm{O} 2)$ & $-167.4(3)$ & $-37.4(2)$ & $-161.5(3)$ & $-37.1(4)(\mathrm{N} 8-\mathrm{C} 52-\mathrm{C} 46-\mathrm{O} 4)$ \\
$\tau_{6}(\mathrm{C} 13-\mathrm{C} 14-\mathrm{C} 18-\mathrm{O} 2)$ & $23.1(4)$ & $-15.1(2)$ & $14.9(4)$ & $-15.8(5)(\mathrm{C} 41-\mathrm{C} 42-\mathrm{C} 46-\mathrm{O} 4)$
\end{tabular}

Table 7 Intra- and intermolecular interactions of 3A, 3B and 3C

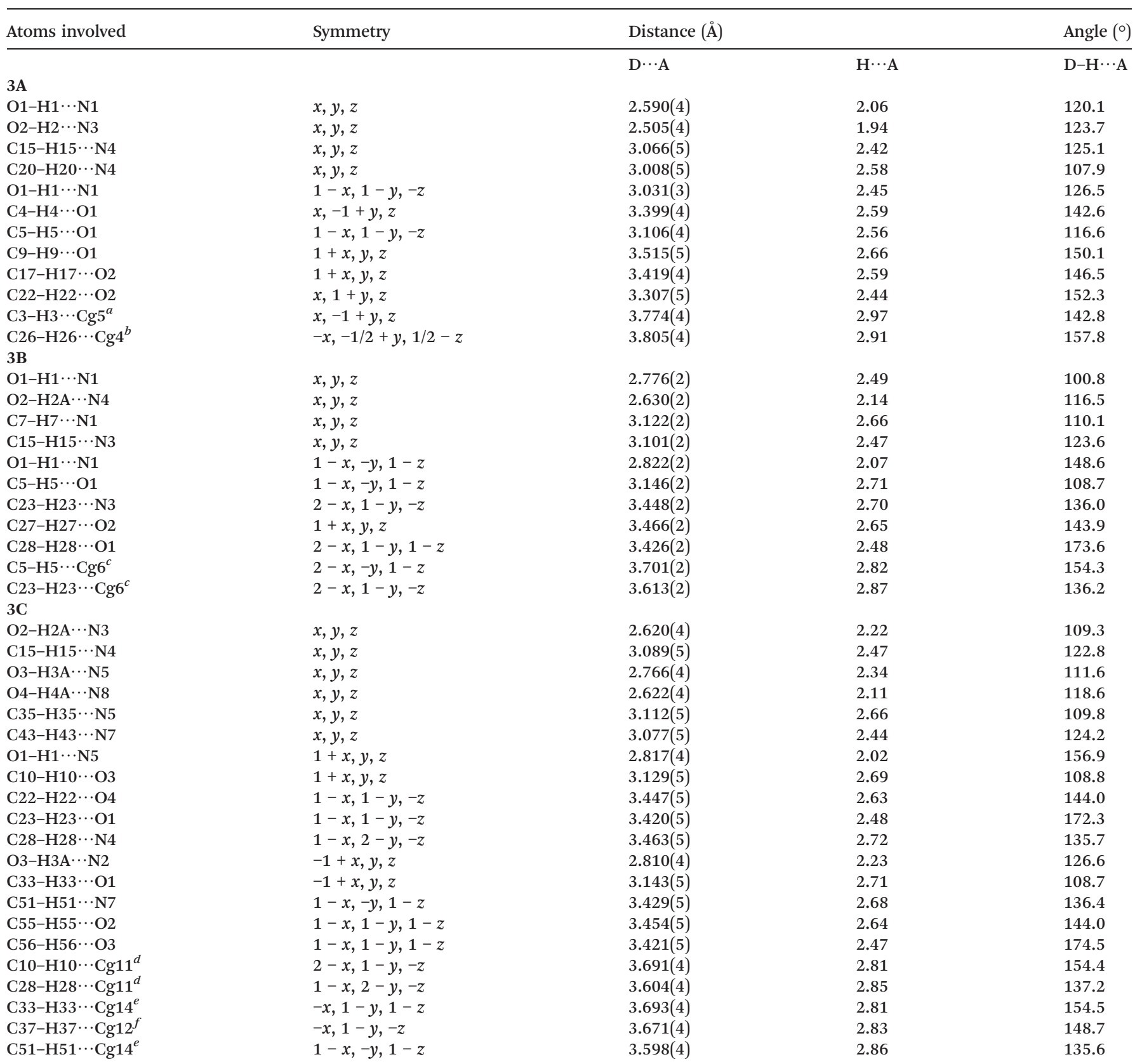

${ }^{a} \mathrm{Cg} 5$ is defined as the geometric centre of $\mathrm{C} 12-\mathrm{C} 17 .{ }^{b} \mathrm{Cg} 4$ is defined as the geometric centre of $\mathrm{C} 24-\mathrm{C} 28$ and $\mathrm{N} 4 .{ }^{c} \mathrm{Cg} 6$ is defined as the geometric centre of $\mathrm{C} 25-\mathrm{C} 26 .{ }^{d} \mathrm{Cg} 11$ is defined as the geometric centre of $\mathrm{C} 20-\mathrm{C} 21 .{ }^{e} \mathrm{Cg} 14$ is defined as the geometric centre of $\mathrm{C} 53-\mathrm{C} 54$.

${ }^{f} \mathrm{Cg} 12$ is defined as the geometric centre of $\mathrm{C} 27-\mathrm{C} 28$. 
(a)

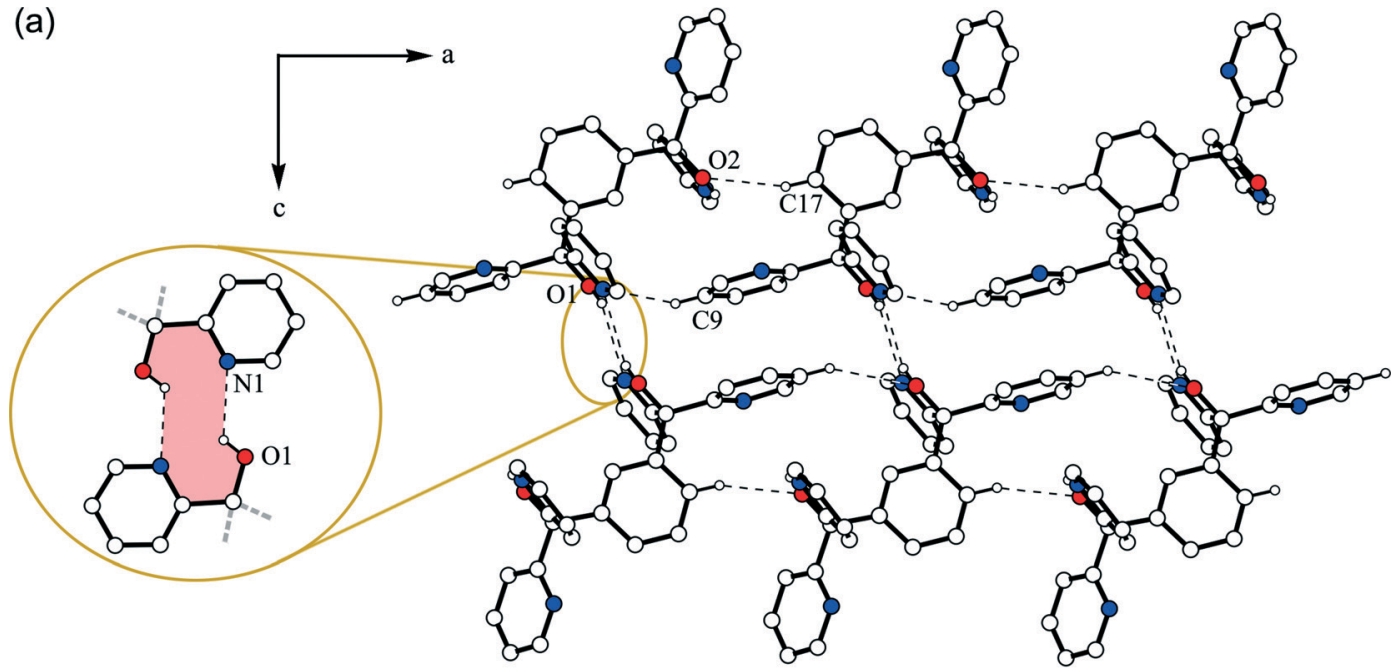

(b)
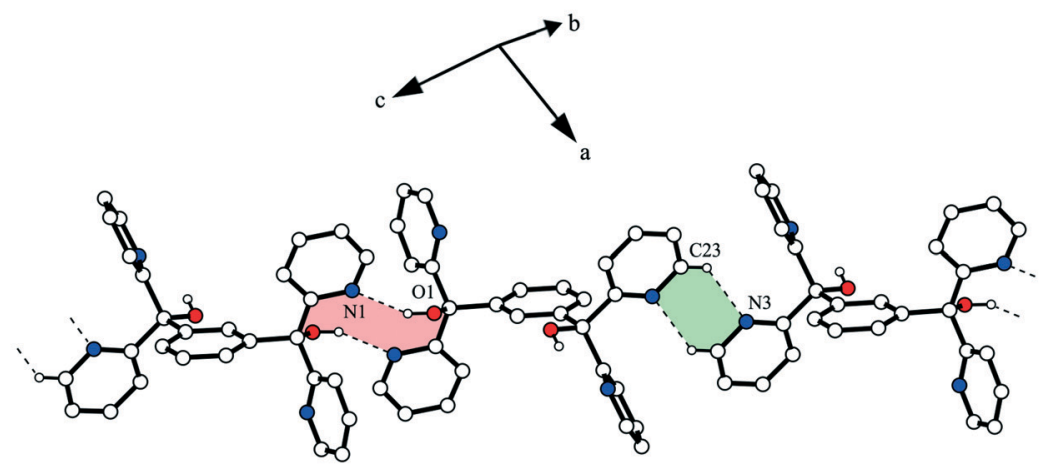

(c)
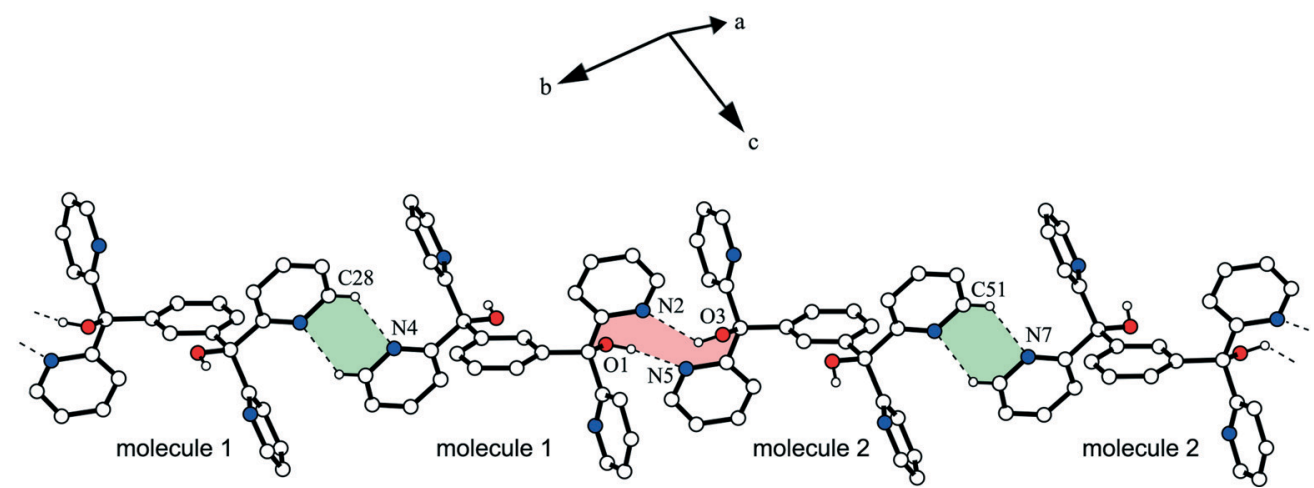

Fig. 11 Dimer strand in the packing structure of $3 \mathrm{~A}(\mathrm{a})$ involving $\mathrm{O}-\mathrm{H} \cdots \mathrm{N}$ and $\mathrm{C}-\mathrm{H} \cdots \mathrm{O}$ interactions. The hydrogen bond ring motif $\mathrm{R}_{2}^{2}(10)$ within the dimer is highlighted. Molecular chains of polymorphs 3B (b) and $3 \mathrm{C}$ (c) involving $\mathrm{O}-\mathrm{H} \cdots \mathrm{N}$ and $\mathrm{C}-\mathrm{H} \cdots \mathrm{N}$ interactions with hydrogen bond ring motifs $R_{2}^{2}(10)$ and $R_{2}^{2}(6)$ being specified. Non-relevant $H$ atoms are omitted for clarity.

$\left(\mathrm{ThC}_{2}\right)$. IR data: $v_{\max } 3528 \mathrm{~m}(\mathrm{OH}), 3104 \mathrm{w}$ and $3069 \mathrm{w}\left(\mathrm{CH}_{\mathrm{Ar}}\right)$, 2923w, 2854w, 1929w, 1806w, 1632w, 1502w, 1426m (OH), $1407 \mathrm{~m}, 1353 \mathrm{~m}(\mathrm{C}=\mathrm{C}), 1312 \mathrm{~m}, 1233 \mathrm{~m}(\mathrm{C}=\mathrm{C}), 1169 \mathrm{w}, 1131 \mathrm{w}$, $1109 \mathrm{w}, 1084 \mathrm{w}, 1040 \mathrm{w}, 1021 \mathrm{w}, 989 \mathrm{~m}, 875 \mathrm{w}, 853 \mathrm{~m}, 837 \mathrm{~m}$, $818 \mathrm{~m}, 796 \mathrm{~m}, 780 \mathrm{~m}, 701 \mathrm{~s}(\mathrm{CH}), 631 \mathrm{w}, 508 \mathrm{w}, 470 \mathrm{w}$. MS data (ESI): calc. for $\mathrm{C}_{24} \mathrm{H}_{18} \mathrm{O}_{2} \mathrm{~S}_{4}$ (466.02), found: $488.9 \mathrm{~m} / \mathrm{z}[\mathrm{M}+$ $\mathrm{Na}]^{+}$. Anal. calc. for $\mathrm{C}_{24} \mathrm{H}_{18} \mathrm{O}_{2} \mathrm{~S}_{4}$ : C, 61.77; H, 3.89; S, 27.48, found: C, $61.80 ; \mathrm{H}, 3.91 ; \mathrm{S}, 26.94 \%$.
1,3-Bis[di(pyrid-2-yl)hydroxymethyl]benzene (3). For the reaction, an analogous procedure to for 1 was applied although isophthaloyl chloride $(0.63 \mathrm{~g}, 3.1 \mathrm{mmol})$ was used instead of terephthaloyl chloride. Purification of the compound was achieved as follows. The residue resulting from solvent removal was column chromatographed on silica gel (EtOAc, $R_{\mathrm{f}}: 0.59$ ) and the evaporated eluate was stirred for 20 min in $10 \mathrm{ml}$ of acetone. The solid was collected by filtration 


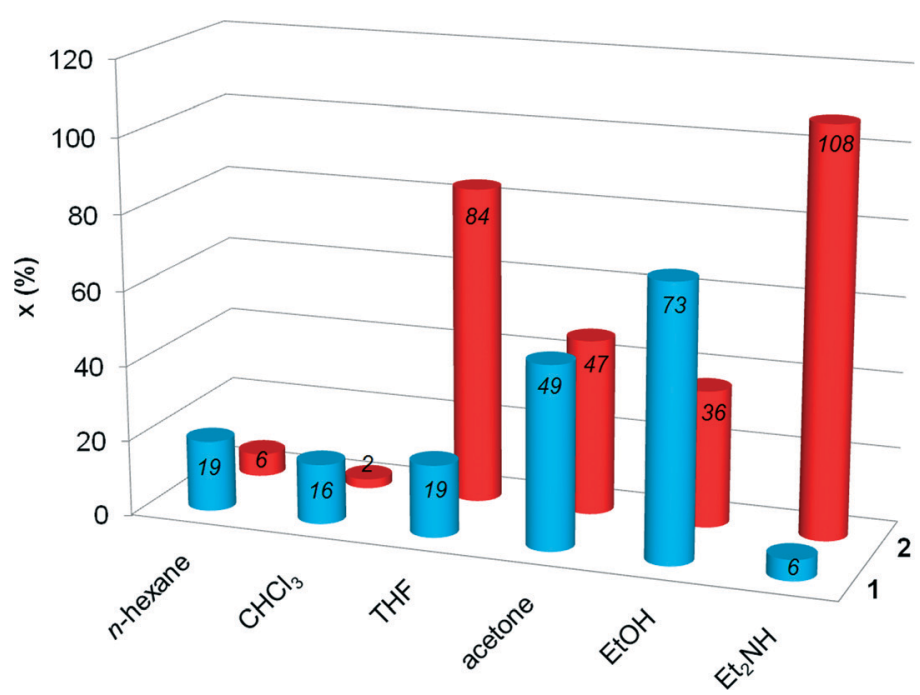<smiles>[R]C([R])(O)c1ccc(C([R])([R])O)cc1</smiles>
$\mathrm{R}=$<smiles>Cc1ccccn1</smiles>

1

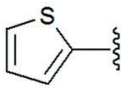

2

Fig. 12 Sorption behavior of the pyridino and thiopheno diol hosts 1 and 2 with respect to the used solvents $(n$-hexane, CHCl 3 , THF, acetone, $\mathrm{EtOH}$, and $\mathrm{Et}_{2} \mathrm{NH}$ ).

and dried to yield compound 3 as a beige powder $(0.29 \mathrm{~g}$, 33\%). Mp 196-199 ${ }^{\circ} \mathrm{C}$ (from acetone). NMR data: $\delta_{\mathrm{H}}(500.1$ MHz, $\left.\mathrm{CDCl}_{3}, \mathrm{TMS}\right) 6.80(2 \mathrm{H}, \mathrm{s}, \mathrm{OH}), 7.13\left(4 \mathrm{H}, \mathrm{td}, \mathrm{PyH}_{5}, J_{\mathrm{HH}}=\right.$ 7.35, 4.85, $1.15 \mathrm{~Hz}), 7.19-7.23(4 \mathrm{H}, \mathrm{m}, \mathrm{Ph}), 7.60(4 \mathrm{H}, \mathrm{td}$, $\left.\mathrm{PyH}_{4}, J_{\mathrm{HH}}=7.40,1.80 \mathrm{~Hz}\right), 7.67\left(4 \mathrm{H}, \mathrm{dt}, \mathrm{PyH}_{3}, J_{\mathrm{HH}}=8.05\right.$, $1.10 \mathrm{~Hz}), 8.45\left(4 \mathrm{H}, \mathrm{m}, \mathrm{PyH}_{6}\right) . \delta_{\mathrm{C}}\left(125.8 \mathrm{MHz} \mathrm{CDCl}_{3}\right) 80.4(\mathrm{C}-$ $\mathrm{OH}), 122.0\left(\mathrm{PyC}_{5}\right), 123.1\left(\mathrm{PyC}_{3}\right), 126.7,127.6,127.9(\mathrm{Ph})$, 136.3 $\left(\mathrm{PyC}_{4}\right), 145.6(\mathrm{Ph}), 147.2\left(\mathrm{PyC}_{6}\right), 163.1\left(\mathrm{PyC}_{2}\right)$. IR data: $v_{\max } 3354 \mathrm{~m}(\mathrm{OH}, \mathrm{br}), 3056 \mathrm{w}$ and $3009 \mathrm{w}\left(\mathrm{CH}_{\mathrm{Ar}}\right), 2923 \mathrm{w}, 1584 \mathrm{~s}$ and $1568 \mathrm{~m}(\mathrm{C}=\mathrm{C}), 1467 \mathrm{~s}(\mathrm{C}=\mathrm{N}), 1432 \mathrm{~s}(\mathrm{OH}), 1372 \mathrm{~m}, 1296 \mathrm{w}$, $1204 \mathrm{w}, 1150 \mathrm{w}, 1103 \mathrm{w}, 1049 \mathrm{~m}$ (C-O), 1002m, 941m, 913w, $802 \mathrm{~m}, 777 \mathrm{~m}, 751 \mathrm{~s}(\mathrm{CH}), 713 \mathrm{~m}, 681 \mathrm{w}, 656 \mathrm{~m}(\mathrm{OH}), 644 \mathrm{w}$, 622w, 584w, 555w, 504w. MS data (ESI): calc. for $\mathrm{C}_{28} \mathrm{H}_{22} \mathrm{~N}_{4} \mathrm{O}_{2}$ (446.17), found: $447.2 \mathrm{~m} / \mathrm{z}[\mathrm{M}+\mathrm{H}]^{+}$. Anal. calc. for $\mathrm{C}_{28} \mathrm{H}_{22} \mathrm{~N}_{4} \mathrm{O}_{2}$ : C, 75.32; H, 4.97; N, 12.55, found: $\mathrm{C}, 75.04 ; \mathrm{H}$, $4.91 ; \mathrm{N}, 12.25 \%$.

\section{Preparation of crystalline inclusion compounds}

The host compound was dissolved by heating in a minimum amount of the respective guest solvent. After storage for $12 \mathrm{~h}$ at room temperature, the crystals which formed were collected and dried ( $1 \mathrm{~h}, 15$ Torr, room temperature). The host: guest stoichiometric ratios were determined by ${ }^{1} \mathrm{H}-\mathrm{NMR}$ integration. The data for each compound are given in Table 1.

\section{$\mathrm{X}$-ray structure determination}

Crystals of inclusion compounds $\mathbf{1 a}, \mathbf{1 b}, \mathbf{2 a}$, and $\mathbf{2 b}$ suitable for X-ray diffraction were obtained by slow evaporation of solutions of 1 and 2 in the respective solvents (1,4-dioxane for $1 \mathrm{a}$, toluene for $\mathbf{1 b}, 1,4$-dioxane for $\mathbf{2 a}$, and pyrrolidine for 2b). Crystals of the guest-free compound 1 were grown from DMSO and those of polymorphs $\mathbf{3 A}, \mathbf{3 B}$ and $3 \mathrm{C}$ from acetone, $\mathrm{CHCl}_{3}$ and 1,4-dioxane, respectively. The intensity data were collected at $100 \mathrm{~K}$ using a Bruker Kappa diffractometer equipped with an APEX II CCD area detector and graphite- monochromatized Mo $\mathrm{K} \alpha$ radiation $(\lambda=0.71073 \mathrm{~A})$ employing $\varphi$ and $\omega$ scan modes. The data were corrected for Lorentz and polarization effects. Semi-empirical absorption correction was applied using the SADABS program. ${ }^{51}$ The SAINT program ${ }^{51}$ was used for the integration of the diffraction profiles. The crystal structures were solved by direct methods using SHELXS-97 (ref. 52) and refined by full-matrix leastsquares refinement against $F^{2}$ using SHELXL-97. ${ }^{52}$ All nonhydrogen atoms were refined anisotropically. Hydrogen atoms were positioned geometrically and allowed to ride on their parent atoms. Geometrical calculations were performed using PLATON and molecular graphics were generated using SHELXTL. $^{52}$ One thiophene ring of the host molecule in structure $\mathbf{2 b}$ is twice disordered (sof $=0.80$ ). The crystal structure of polymorph $\mathbf{3 A}$ was solved only with a data completeness of $80 \%$. Unfortunately, we were unable to re-isolate this metastable polymorph under the mentioned conditions, putting us into a potential position to use a more complete data set.

\section{Sorption measurements}

For the sorption experiments, a quartz crystal microbalance consisting of two electronic quartzes (10 MHz) with gold electrodes (FOQ Piezo Technik, Germany) was used. The reference quartz is uncoated, while the other quartz is coated with the solid diol compound ( 1 and 2 , respectively). The measurements were carried out at constant temperature (25 $\left.{ }^{\circ} \mathrm{C}\right)$ and with a constant flow of synthetic air $\left(10 \mathrm{~L} \mathrm{~h}^{-1}\right)$. A multichannel frequency counter (HKR Sensor Systems, Munich, Germany) with a resolution of $1 \mathrm{~Hz}$ was used to measure the resonance frequencies of the quartzes which can be read by a computer using a serial interface. The coating of the quartz was realized by dipping in a $0.01 \mathrm{M}$ solution of the respective diol compound in $\mathrm{CHCl}_{3}$. The change in frequency is proportional to the increase in quartz mass induced by the 
sorption of the added solvent vapor. This relation results from the Sauerbrey equation. ${ }^{53}$ In consideration of the molar mass of the used solvents, the percentage of the adsorbed solvent can be obtained.

\section{Acknowledgements}

Financial support from the European Union (European Regional Development Fund) and from the Ministry of Science and Art of Saxony (Cluster of Excellence "Structure Design of Novel High-Performance Materials via Atomic Design and Defect Engineering [ADDE]') is gratefully acknowledged by FK and EW.

\section{References}

1 Comprehensive Supramolecular Chemistry, ed. D. D. MacNicol, F. Toda and R. Bishop, Elsevier, Oxford, U.K., 1996, vol. 6 .

2 T. Hertzsch, J. Hulliger, E. Weber and P. Sozzani, in Encyclopedia of Supramolecular Chemistry, ed. J. L. Atwood and J. W. Steed, CRC Press, Boca Raton, FL, 2004, pp. 996-1005.

3 Organic Solid State Reactions, Topics in Current Chemistry, ed. F. Toda, Springer-Verlag, Berlin/Heidelberg, 2005, vol. 254.

4 Metal-Organic Frameworks: Design and Application, ed. L. R. Gillivray, Wiley, Hoboken, NY, 2010.

5 Inclusion Compounds, ed. J. L. Atwood, J. E. D. Davies and D. D. MacNicol, Oxford University Press, Oxford, U.K., 1991, vol. 4.

6 E. Weber, in Kirk-Othmer Encyclopedia of Chemical Technology, ed. J. I. Kroschwitz, Wiley, New York, 4th edn, 1995, vol. 14, pp. 122-154.

7 A. Nangia, in Nanoporous Materials, ed. G. Q. Lu and X. S. Zhao, Series on Chemical Engineering, Imperial College Press, London, 2004, vol. 4, pp. 165-187.

8 F. H. Herbstein, Crystalline Molecular Complexes and Compounds, Oxford University Press, Oxford, U.K., 2005, vol. 1, pp. 421-513.

9 J. W. Steed and J. L. Atwood, Supramolecular Chemistry, Wiley, New York, 2nd edn, 2009.

10 Organic Crystal Engineering, ed. J. J. Vittal, M. Zaworotko and E. R. T. Tiekink, Wiley, New York, 2010.

11 G. R. Desiraju, Angew. Chem., Int. Ed., 2007, 46, 8342.

12 Making Crystals by Design: Methods, Techniques and Applications, ed. D. Braga and F. Creponi, Wiley-VCH, Weinheim, Germany, 2007.

13 R. Bishop, Chem. Soc. Rev., 1996, 25, 311.

14 G. R. Desiraju, in Comprehensive Supramolecular Chemistry, ed. D. D. MacNicol, F. Toda and R. Bishop, Elsevier, Oxford, U.K., 1996, vol. 6, pp. 1-32.

15 E. Weber, in Inclusion Compounds, ed. J. L. Atwood, J. E. D. Davies and D. D. MacNicol, Oxford University Press, Oxford, U.K., 1991, vol. 4, pp. 188-262.

16 E. Weber and M. Czugler, in Molecular Inclusion and Molecular Recognition: Clathrates II, ed. E. Weber, Topics in
Current Chemistry, Springer-Verlag, Berlin/Heidelberg, 1988, vol. 149, pp. 45-135.

17 F. Toda, in Comprehensive Supramolecular Chemistry, ed. D. D. MacNicol, F. Toda and R. Bishop, Elsevier, U.K., 1996, vol. 6, pp. 465-516.

18 H. Hart, L.-T. W. Lin and D. L. Ward, J. Am. Chem. Soc., 1984, 106, 4043.

19 F. Toda, A. Kai, R. Toyotaka, W.-H. Yip and T. C. W. Mak, Chem. Lett., 1989, 1921.

20 E. Weber, K. Skobridis, A. Wierig and L. R. Nassimbeni, J. Chem. Soc., Perkin Trans. 2, 1992, 2123.

21 E. Weber, in Comprehensive Supramolecular Chemistry, ed. D. D. MacNicol, F. Toda and R. Bishop, Elsevier, U.K., 1996, vol. 6, pp. 535-592.

22 Y. Mazaki, N. Hayashi and K. Kobayashi, J. Chem. Soc., Chem. Commun., 1992, 1381.

23 G. R. Newkome, J. D. Sauer and M. L. Erbland, J. Chem. Soc., Chem. Commun., 1975, 885.

24 C. Bachmann, M. Guttentag, B. Spingler and R. Alberto, Inorg. Chem., 2013, 52, 6055.

25 D. A. Kurmaev, N. A. Kolosov, S. C. Gagieva, A. O. Borissova, V. A. Tuskaev, N. M. Bravaya and B. M. Bulychev, Inorg. Chim. Acta, 2013, 396, 136.

26 C. W. Thornber, Chem. Soc. Rev., 1979, 8, 563.

27 N. Brown, Bioisosters in Medicinal Chemistry, Wiley-VCH, Weinheim, 2012.

28 Piezoelectric Sensors, ed. A. J. C. Steinem and A. Janshoff, Springer-Verlag, Heidelberg, 2006.

29 H. Kurata, M. Inase and M. Oda, Chem. Lett., 1999, 519.

30 A. L. Spek, Acta Crystallogr., Sect. D: Biol. Crystallogr., 2009, 65, 148.

31 M. Nishio, Y. Umezawa, K. Honda, S. Tsuboyama and H. Suezawa, CrystEngComm, 2009, 11, 1757.

32 G. R. Desiraju and T. Steiner, The Weak Hydrogen Bond. In Structural Chemistry and Biology, Oxford University Press, New York, 1999.

33 D. Eißmann, F. Katzsch and E. Weber, Struct. Chem., 2012, 23, 1131.

34 C. Janiak, J. Chem. Soc., Dalton Trans., 2000, 3885.

35 A. I. Kitaigorodskii, Molecular Crystals and Molecules, Academic Press, New York, 1973.

36 M. C. Etter, J. Phys. Chem., 1991, 95, 4601.

37 J. Bernstein, R. E. Davies, L. Shimoni and N.-L. Chang, Angew. Chem., Int. Ed. Engl., 1995, 34, 1555.

38 G. Gilli and P. Gilli, The Nature of the Hydrogen Bond, Oxford University Press, Oxford, 2009.

39 A. Kucsman, I. Kapovits, M. Czugler, L. Parkanyi and A. Kalman, J. Mol. Struct., 1989, 198, 339.

40 R. Gleiter, D. B. Werz and B. J. Rausch, Chem. - Eur. J., 2003, 9, 2676.

41 I.-L. Long, P. Kögerler and L. Cronin, Angew. Chem., Int. Ed., 2004, 43, 1817.

42 M. Mascal, Contemp. Org. Synth., 1994, 1, 31.

43 J. J. Novoa, M. C. Rovira, C. Rovira, J. Veciana and J. Tarres, Adv. Mater., 1995, 7, 233.

44 Piezoelectric Transducers and Applications, ed. A. Arnau, Springer-Verlag, Heidelberg, 2004. 
45 J. W. Grate, Chem. Rev., 2000, 100, 2627.

46 A. Ehlen, C. Wimmer, E. Weber and J. Bargon, Angew. Chem., Int. Ed. Engl., 1993, 32, 110.

47 J. Reinbold, K. Buhlmann, K. Camman, A. Wierig, C. Wimmer and E. Weber, Sens. Actuators, B, 1994, 18/19, 77.

48 U. Schramm, D. Meinhold, S. Winter, C. Heil, J. MüllerAlbrecht, L. Wächter, E. Weber and J. Bargon, Sens. Actuators, B, 2000, 67, 219.
49 D. Schindler, F. Eißmann and E. Weber, Org. Biomol. Chem., 2009, 7, 3549.

50 T. Gruber, C. Fischer, W. Seichter, P. Bombicz and E. Weber, CrystEngComm, 2011, 13, 1422.

51 Bruker, SAINT, SADABS, AXS Inc., Madison, Wisconsin, USA, 2007.

52 G. M. Sheldrick, Acta Crystallogr., Sect. A: Found. Crystallogr., 2008, 64, 112.

53 G. Sauerbrey, Z. Phys., 1959, 155, 206. 